\title{
Paleomagnetic constraints on the extent of tectonic blocks and the location of their kinematic boundaries: Implications for Miocene intra-arc deformation in Northeast Japan
}

\author{
Hiroyuki Hoshi* \\ and Masaki Takahashi**
}

Received March 18, 1996.

Accepted January 27, 1997.

* Department of Environmental Earth Sciences, Aichi University of Education, Kariya 448, Japan

** Fuel Resources Department, Geological Survey of Japan, Tsukuba 305, Japan

\begin{abstract}
Recent paleomagnetic investigations suggest that Miocene intra-arc deformation resulted in differential rotation within Northeast (NE) Japan. In order to clarify the areal extent of each rotated (or unrotated) block, we carried out paleomagnetic surveys in the Motegi area in the southern part of NE Japan. We obtained a total of 81 reliable site-mean directions from volcanic rocks and have interpreted these in combination with 26 previously reported paleomagnetic direction sites. Early Miocene andesitic to basaltic lava flows and sills displayed north-south seeking directions, suggesting no vertical-axis rotation took place since their emplacement. The stability of the north-south remanent magnetization directions was confirmed through both a conglomerate test and a reversals test. Recent chronological results provide strict age control for their emplacement ; the sills were emplaced at about $18 \mathrm{Ma}$ and the flows at about $17 \mathrm{Ma}$. A calculation of the amount of vertical-axis rotation based on directional data from the sills with respect to the North China Block in the Asian continent (rotation estimate and its uncertainty $\left.=-3.8 \pm 9.1^{\circ}\right)$ indicates no detectable vertical-axis rotation in the study area after $18 \mathrm{Ma}$. This result, combined with other paleomagnetic data from the frontal region of northern Honshu, leads us to conclude that the frontal region, including the study area, has been a coherent rigid block since at least $16 \mathrm{Ma}$, and that it has not experienced vertical-axis rotation since that time. On the other hand, the Kanto Mountains in central Japan are known to have rotated clockwise through more than $90^{\circ}$ between 15 and $6 \mathrm{Ma}$. Hence, it is clear that a large relative rotation has occurred between the frontal region of northern Honshu and the Kanto Mountains during Middle to Late Miocene time. We consider that the Kanto Tectonic Line has been an active block boundary during this period. In addition, our conclusion argues against a previous claim that the northern half of NE Japan rotated counter-clockwise at about $15 \mathrm{Ma}$; our data implies that the counter-clockwise rotation of NE Japan had already ended by 15 Ma.
\end{abstract}

Key words : intra-arc deformation, kinematic block boundary, Miocene, Motegi area, Northeast Japan, paleomagnetism, tectonic rotation, tectonics of the Japan Arc
Introduction

The Japan Arc-Japan Sea pair is one of the many arc-marginal basin systems that characterize the western Pacific. The Japan Arc is divided into two geologic domains, Northeast (NE) Japan and Southwest (SW) Japan, the boundary being located in the central part of the arc (central Japan). NE Japan extends from the Itoigawa-Shizuoka Tectonic Line (ISTL) to central Hokkaido (Kimura et al., 1991) (Fig. 1). 


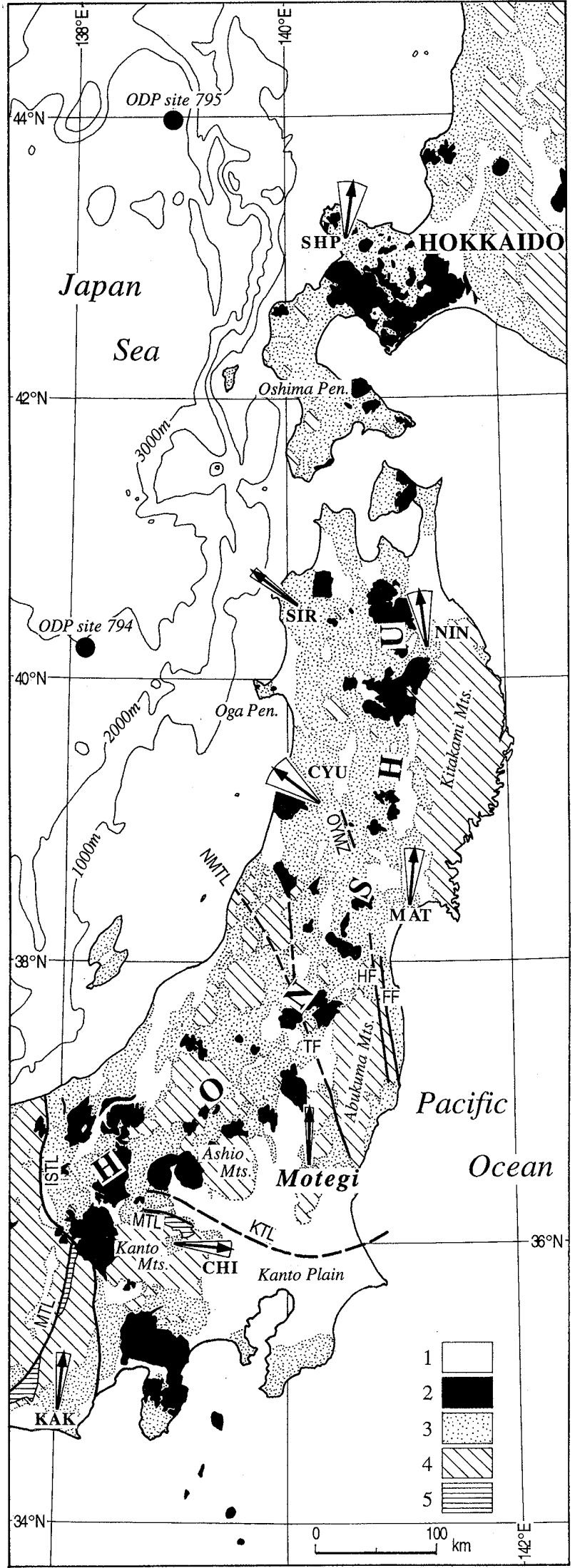

During the Miocene, several remarkable tectonic events occurred in and around the Japan Arc. Most sections of the Japan Sea floor were formed in this period (Kono, 1986 ; Tamaki, 1986, 1988 ; Kaneoka, 1990 ; Burckle et al., 1992 ; Ingle, 1992 ; Kaneoka et al., 1992 ; Pouclet and Bellon, 1992 ; Nakasa and Kinoshita, 1994 ; Otofuji, 1996). The formation of the present arcuate shape of the Japan Arc was related to this backarc basin opening (Otofuji, 1996, and references therein). The collision of the Izu-Bonin Arc with the Japan Arc began in the early Middle Miocene (Amano, 1991 ; Koyama, 1991 ; Takagi et al., 1993). The lateral bending of zonal geologic structures in central Japan may have resulted from this collision (Itoh, 1988 ; Itoh and Ito, 1989 ; Takahashi, 1994).

From the viewpoint of paleomagnetic rotation, NE Japan seems to have been a multi-block system in Miocene time. Otofuji et al. (1994) concluded that northern Honshu and southwest Hokkaido, the region from latitudes $38^{\circ} \mathrm{N}$ to $43^{\circ} \mathrm{N}$, rotated counter-clockwise at about $15 \mathrm{Ma}$ as a single rigid block in association with the opening of the Japan Sea. Yamazaki (1989) and Hayashida (1994 a), however, disclosed that the Early to Middle Miocene $(\sim 16 \mathrm{Ma})$ sedimentary rocks in the vicinity of the Kitakami Mountains retained north-south paleomagnetic declinations (Fig. 1), suggesting no rotation in the mountains since 16 Ma. Paleomagnetic directions of some sedimentary basins in central Hokkaido indicate a $30-10^{\circ}$ verticalaxis clockwise rotation since the Middle Miocene (Kodama et al., 1993). In addition, paleomagnetic results from the Kanto Mountains (Hyodo and Niitsuma, 1986 ; Takahashi and Nomura, 1989 ; Takahashi and Watanabe, 1993) indicate that more than $90^{\circ}$ of clockwise rotation occurred during a period between 15 and $6 \mathrm{Ma}$. Paleomagnetic data from the southwestern part of NE Japan near ISTL

Fig. 1. Simplified geological map of Northeast Japan, showing location of the Motegi area. Selected paleomagnetic declinations of late Early Miocene (about 18 to $16 \mathrm{Ma}$ ) rocks are also plotted. The mean declinations are indicated by arrows together with their $95 \%$ confidence limits $\left(=\sin ^{-1}\left[\sin \alpha_{95} / \cos I\right.\right.$, where $\alpha_{95}$ is the radius of the $95 \%$ confidence circle and $I$ is the inclination). 1: Quaternary sediments. 2: Quaternary volcanic products. 3 : Tertiary rocks. 4 : pre-Tertiary rocks, except Sanbagawa metamorphic rocks (5). MTL : Median Tectonic Line. ISTL : Itoigawa-Shizuoka Tectonic Line. KTL : Kanto Tectonic Line. TF : Tanakura Fault. HF : Hatakawa Fault. FF : Futaba Fault. NMTL : NihonkokuMiomote Tectonic Line. OYMZ: Onikobe--Yuzawa Mylonite Zone. KAK: Kakegawa area (Hayashida, 1994b). CHI : Chichibu basin (Hyodo and Niitsuma, 1986). MAT : Matsushima area (Yamazaki, 1989). NIN : Ninohe area (Hayashida, 1994a). CYU : ChokaiYuzawa area (Otofuji et al., 1994). SIR : Shirakami area (Otofuji et al., 1994). SHP : Shakotan Peninsula (Tanaka et al., 1991). 


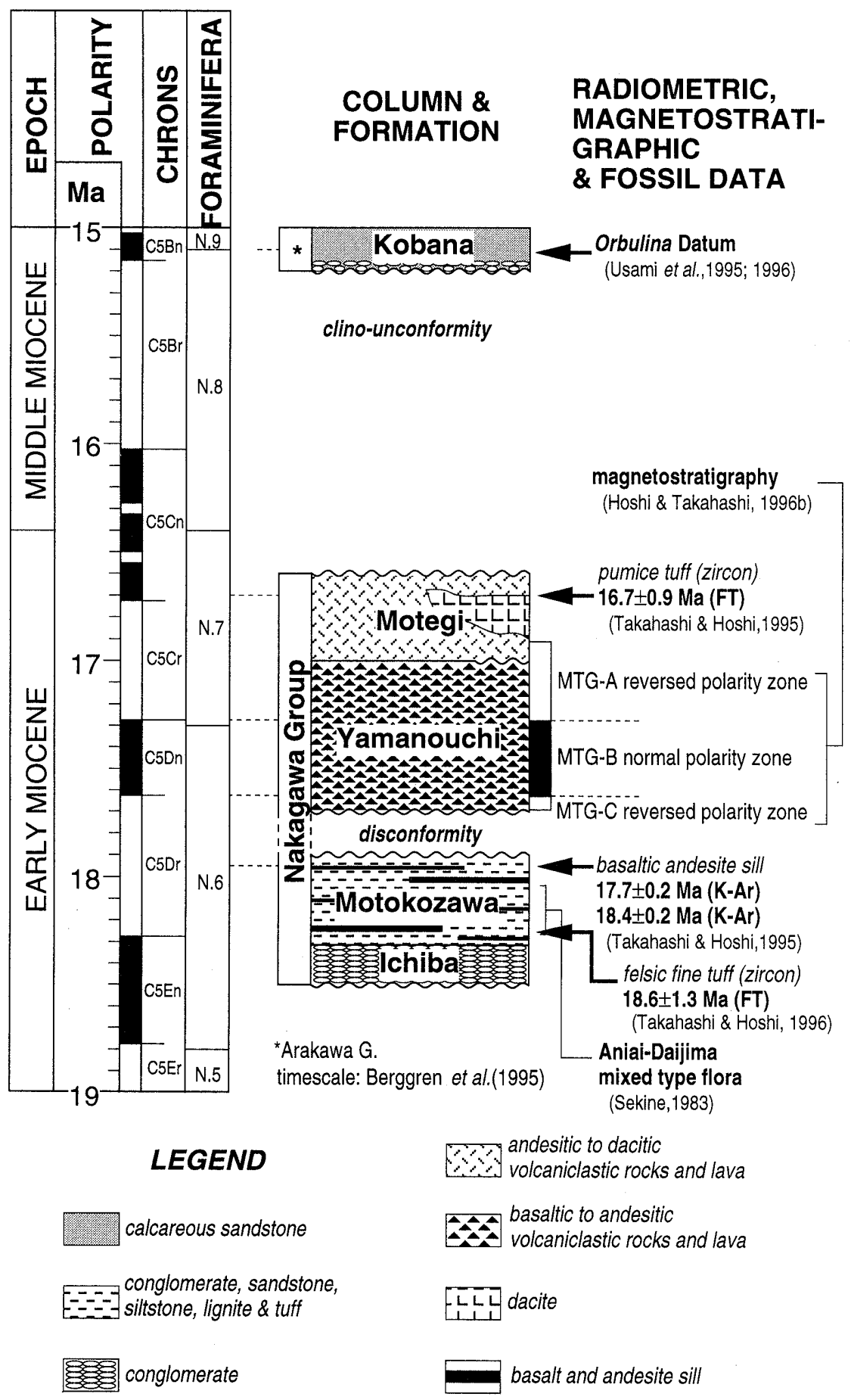

Fig. 2. Generalized stratigraphy of the Early Miocene sequence in the Motegi area (modified from Hoshi and Otsuki, 1996). Errors in radiometric ages are shown in 1 sigma.

also implies an Early to Middle Miocene complicated crustal deformation event with vertical-axis rotation (Hirooka et al., 1990). Selected paleomagnetic declinations of late Early Miocene (about 18 to $16 \mathrm{Ma}$ ) rock units are shown in Fig. 1. Magnetic directions with diverse declination suggest complex intra-arc deformation with differential rotation within NE Japan in late Cenozoic time. This intra-arc deformation within NE Japan inferred from paleomagnetism must have been related to the remarkable tectonic events mentioned above. Hence, it is crucial to clarify the amount of each block rotation, the areal extent of rotated (or unrotated) blocks and the location of block boundaries in order to understand the geodynamic evolution of the Japan Arc during the opening of the Japan Sea.

This paper presents newly obtained paleomagnetic data from Early Miocene volcanic rocks of the Motegi area (Fig. 1). Hoshi and Takahashi (1996 b) have previously reported 26 site-mean paleomagnetic directions and discussed magnetostratigraphic constraints for the time of volcanic activity. The data they ob- 


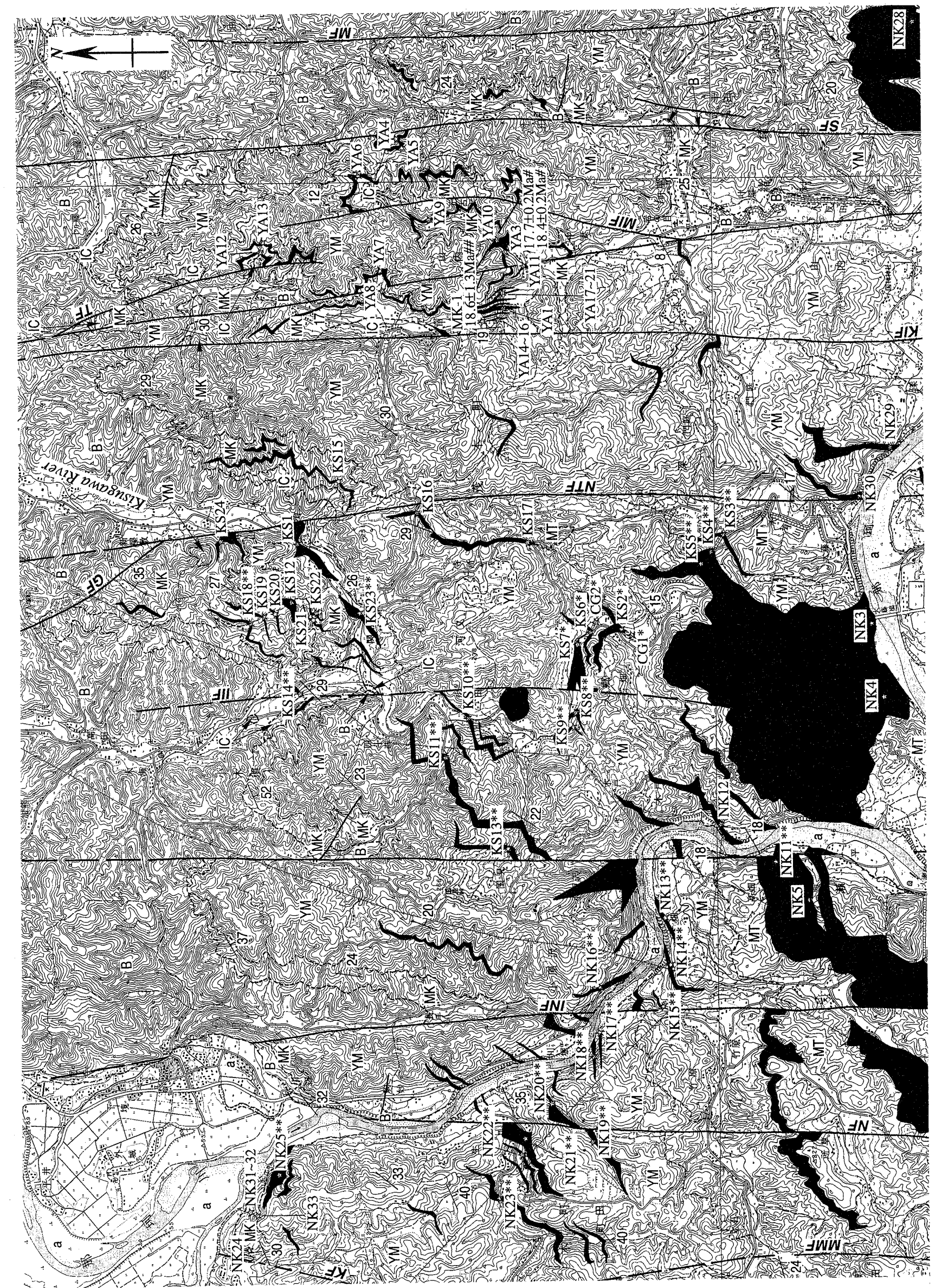



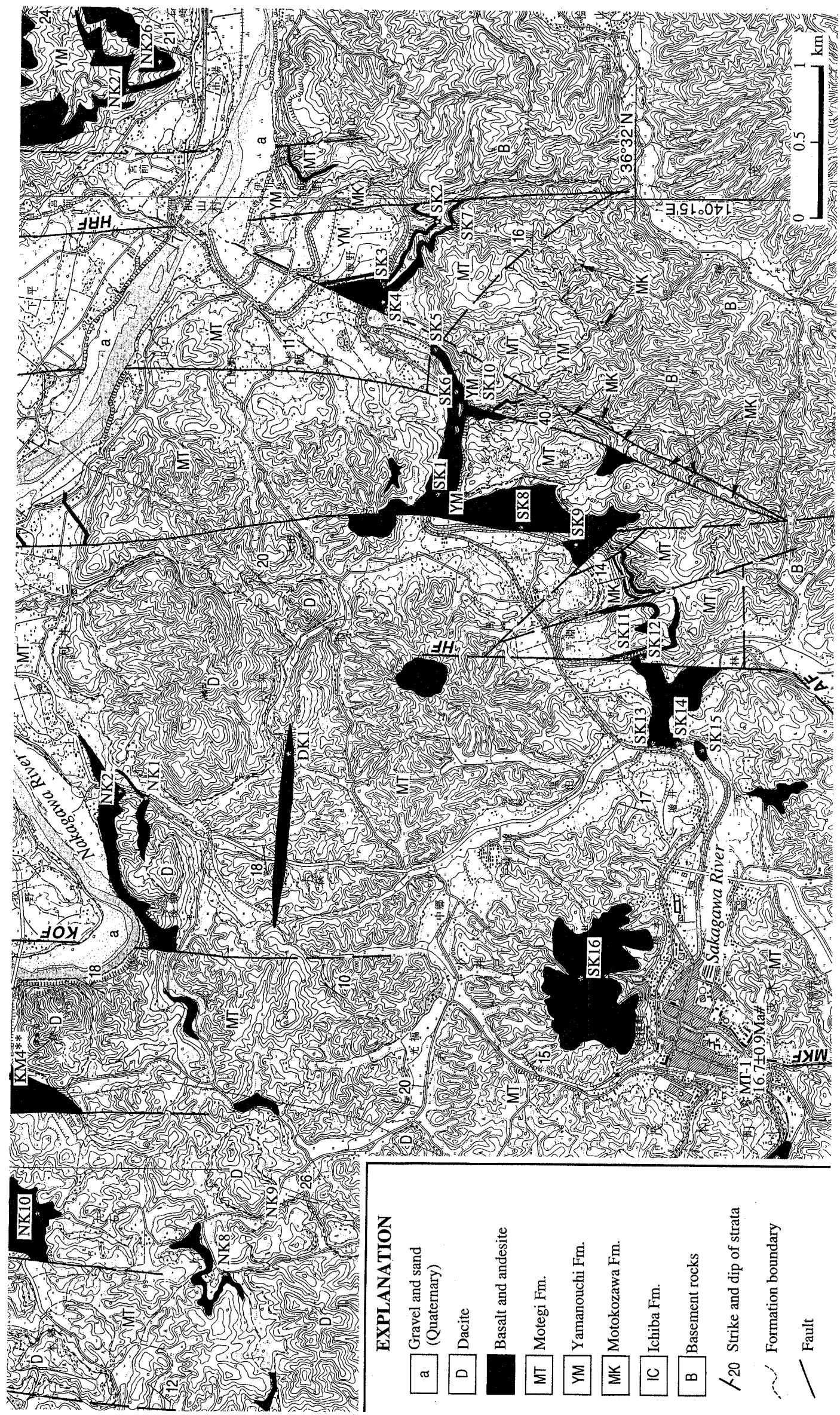

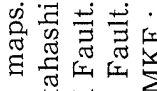

的然

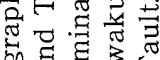

so 둥 ह

过경

ه

要州留

을 落

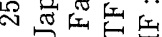

$\because 4 \pi z$

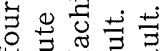

政

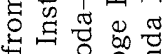

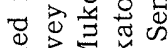

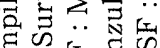

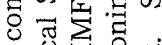

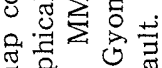

雪

\&

๑ 0

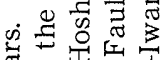

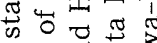

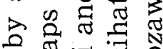

켠

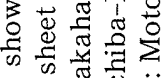

t。․․․․

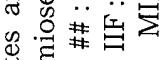

क苗站

20

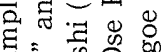

o

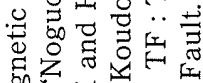

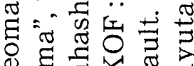

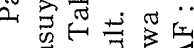

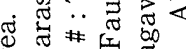

ส

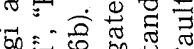

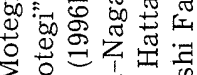

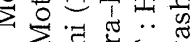

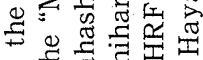

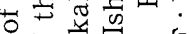

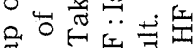

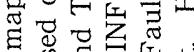

बा त

구의

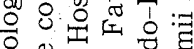

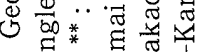

क口

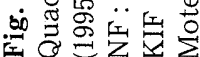


tained was highly reliable, but more data was necessary in order to quantify the amount of vertical-axis rotation in the area and to test the areal extent of regional-scale crustal blocks and the location of their boundaries. Combining our sampling with the previous data, a total of 81 reliable site-mean directions were obtained from numerous, separate rock units. We show, through calculating the amount of verticalaxis rotation with respect to the Asian continent, that the Motegi area has not undergone vertical-axis rotation since $18 \mathrm{Ma}$. Taken into consideration with published paleomagnetic data from the frontal region of northern Honshu (Hirooka et al., 1986 ; Yamazaki, 1989 ; Hayashida, 1994 a), it is evident that relative rotation has not occurred between the frontal region (including the Motegi area) and the Asian continent since at least $16 \mathrm{Ma}$. The areal extent and time of intra-arc block rotation and the boundary between blocks are then discussed. Our conclusion also delimits the timing of the counter-clockwise rotation of NE Japan.

\section{Geologic setting}

The Lower Miocene strata in the Motegi area, called the Nakagawa Group (Kawada, 1947), unconformably overlie Paleozoic and Mesozoic basement rocks. From base to top the group consists of the following four formations; the Ichiba, Motokozawa, Yamanouchi, and Motegi Formations (Kawada, 1953 ; Hoshi and Takahashi, 1996 a). The stratigraphy and geology of the study area are shown in Figs. 2 and 3, respectively. The following brief description of the lithofacies and geologic structures of the Nakagawa Group is based on reports by Hoshi and Takahashi (1996 a, b).

The Ichiba Formation consists of conglomerates, with no fossils discovered to date. The Motokozawa Formation, which conformably overlies the Ichiba Formation, consists of lacustrine and swamp deposits, and contains small amounts of volcaniclastic sediments. Laminated siltstones within the formation contain many plant fossils belonging to the "AniaiDaijima mixed type flora” (Sekine, 1983 ; Suzuki, 1989). Numerous non-porphyritic basalt sills (the Motokozawa Basalt : Shuto et al., 1985 ; Hoshi and Takahashi, $1996 \mathrm{~b}$ ) and a few basaltic andesite sills intrude this formation. The Yamanouchi Formation is composed of basaltic to andesitic volcaniclastic rocks and lava flows, and disconformably overlies the Neogene strata. The Motegi Formation covers about half the study area and consists mainly of felsic tuffs, basaltic to dacitic lava flows and their reworked clastic sediments. In the Karasuyama area, northwest of the study area, a thick marine sequence of the Arakawa Group covers the Nakagawa Group with an angular unconformity. The Arakawa Group is composed of fossil-rich sedimentary rocks with frequent intercala- tions of tuff layers (Kawada, 1953 ; Sakai, 1986).

The geologic structure of the study area is characterized by an asymmetric basin structure and the occurrence of north-south striking faults (Hoshi and Takahashi, $1996 \mathrm{a}$ ). Strata in the southern part of the area lie almost horizontally, whereas those in the northern part dip moderately $\left(<\sim 40^{\circ}\right)$ south or southeast. Based on field evidence, the north-south striking faults formed prior to the deposition of the Arakawa Group (Hoshi and Takahashi, 1996 a ; Hoshi and Otsuki, 1996). Structural data from the fault rocks (Hoshi and Takahashi, $1996 \mathrm{a}$ ) indicates that the initial and latest movements on the faults were dominated by dip-slip (normal-slip) and strikeslip (dextral ?), respectively. Structural disturbances near the faults, such as overturned strata and changes in bedding attitude, are rarely observed.

Recent biostratigraphic, radiometric, and magnetostratigraphic studies reveal that the Nakagawa Group ranges from about 19 to $16.5 \mathrm{Ma}$ (Fig. 2). Preliminary paleontological results from the Arakawa Group (Usami et al., 1995, 1996) estimate the depositional age of the lowermost part of the group at about 15.1 Ma (Takahashi and Hoshi, 1996). This estimation gives an age constraint for the younger limit of the underlying Nakagawa Group. Radiometric dates (Takahashi and Hoshi, 1995, 1996) obtained from the Nakagawa Group are summarized in Fig. 2.

Hoshi and Takahashi (1996 b) detected a reversednormal-reversed ( $\mathrm{R}-\mathrm{N}-\mathrm{R}$ ) magnetic polarity sequence from a volcanic succession of the Yamanouchi and Motegi Formations. This polarity sequence can be correlated to Chron C5Dr-C5Dn-C5Cr (18.281-16.726 Ma) of Cande and Kent (1995) (Hoshi and Takahashi, $1996 \mathrm{~b}$ ). Considering the fission-track age of the Motokozawa Formation (Takahashi and Hoshi, 1996), the reversely-magnetized Motokozawa Basalt probably intruded during Chron C5Dr (18.281-17.615 Ma), although Hoshi and Takahashi (1996b) suggested correlation is possible with both Chron C5Dr and Chron C $5 \mathrm{Er}(19.048-18.781 \mathrm{Ma})$.

\section{Sampling and measurement}

Additional sampling concentrated on basalt and andesite lava flows of the Motegi (16 sites) and Yamanouchi (15) Formations, the Motokozawa Basalt (22) and basaltic andesite sills (6) intruding the Motokozawa Formation, and basalt and andesite dikes (5). An attempt was made to cover the study area as uniformly as possible. We collected samples mainly along rivers and roads (Fig. 3) ; most sites providing fresh surfaces. Since sampling and laboratory procedures are fundamentally identical to that of Hoshi and Takahashi (1996 b), only a synopsis of the procedures will be given.

At each site, a minimum of four core samples were taken with a portable coring drill. Samples were 


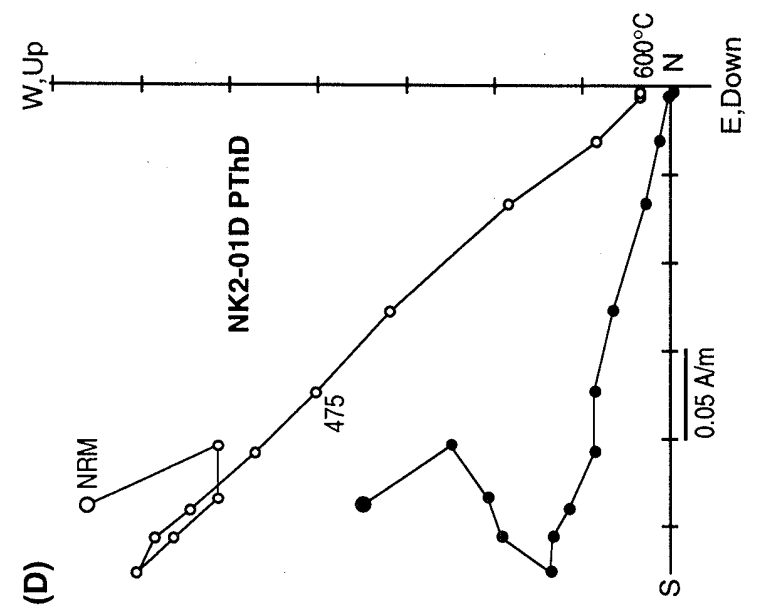

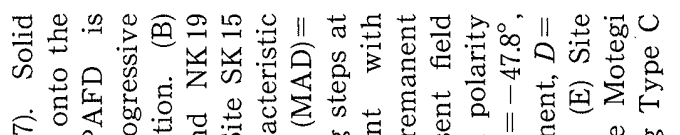

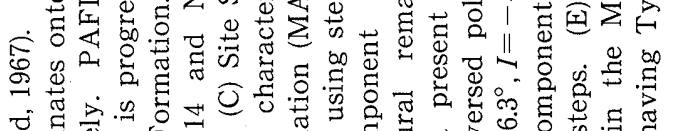

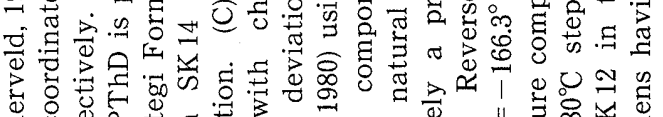

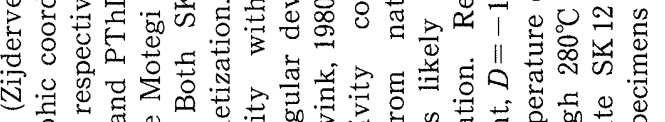

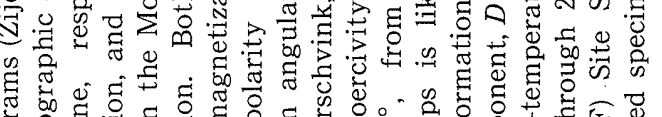

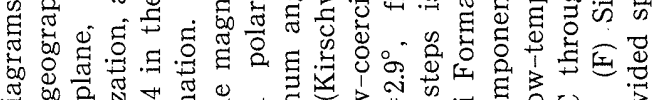

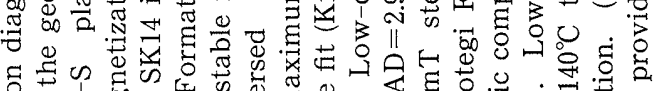

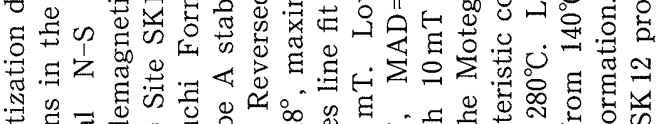

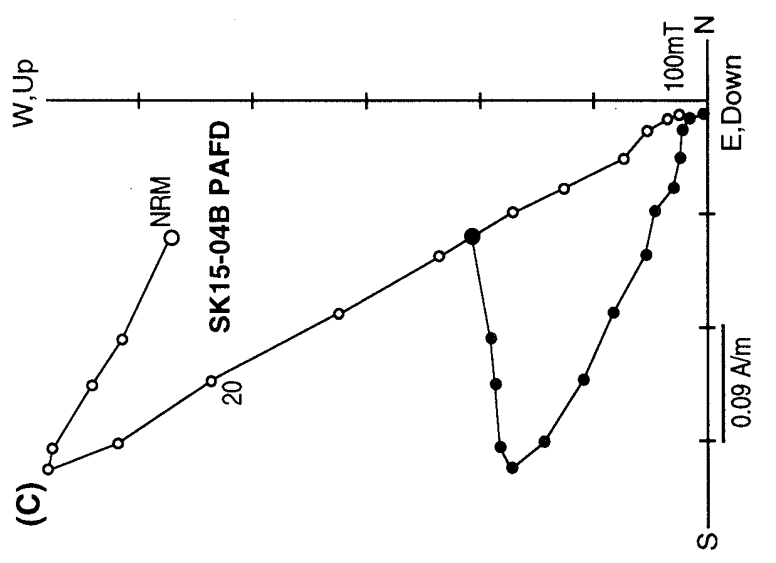

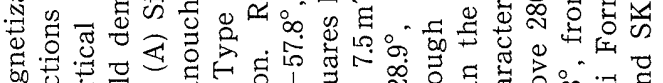

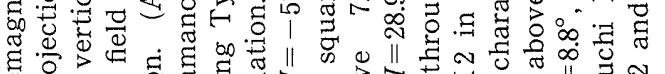

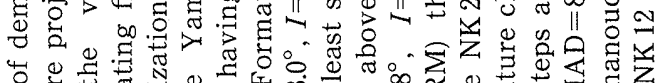

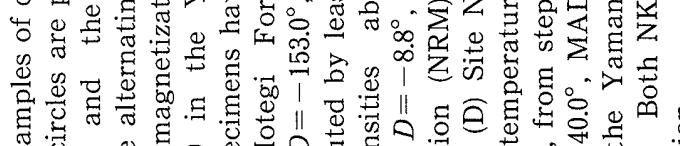

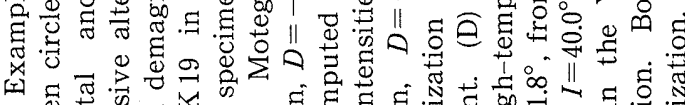
+

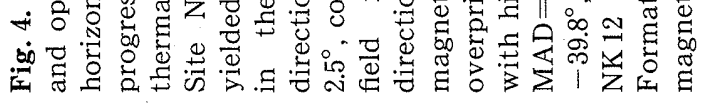
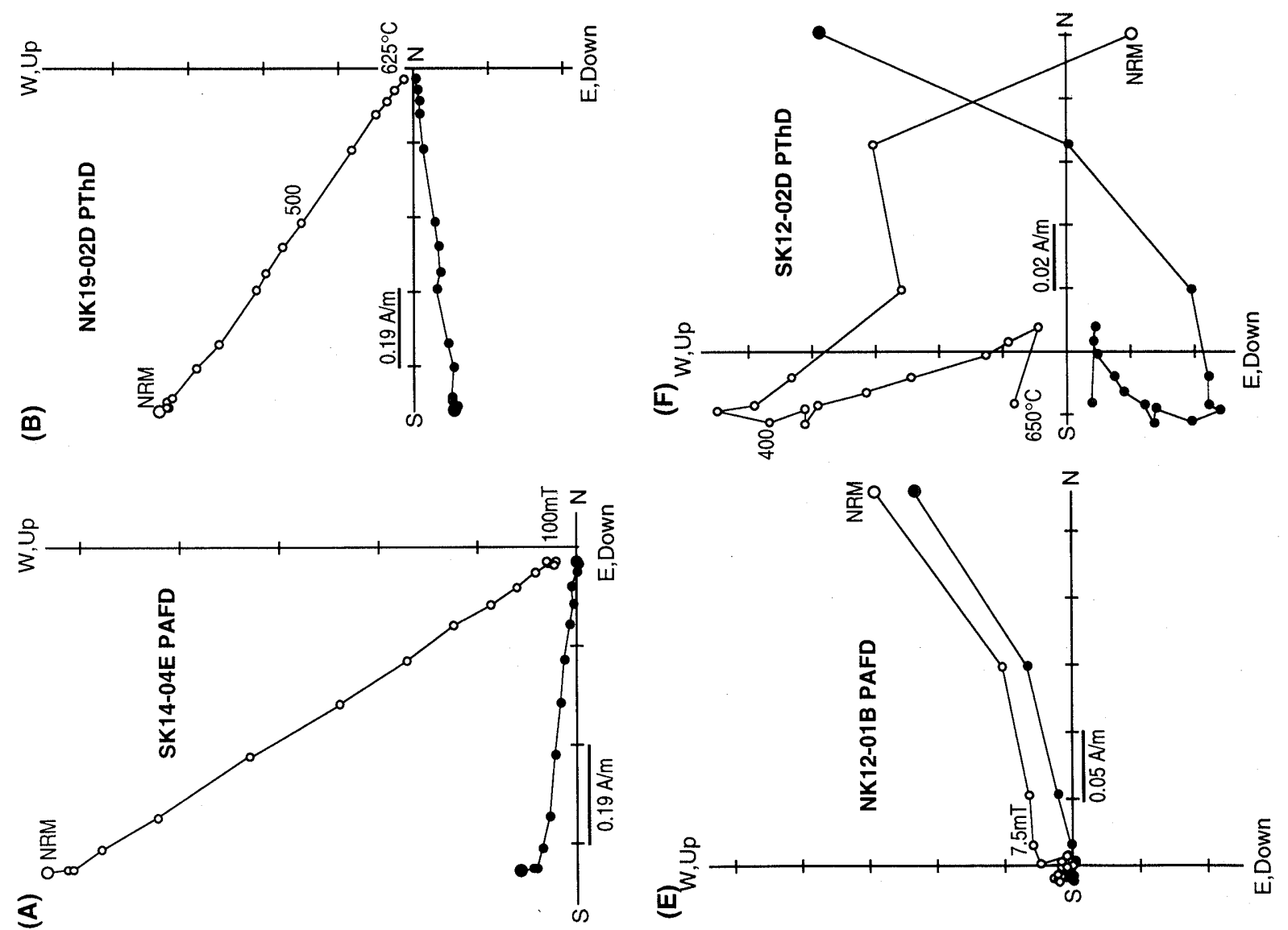


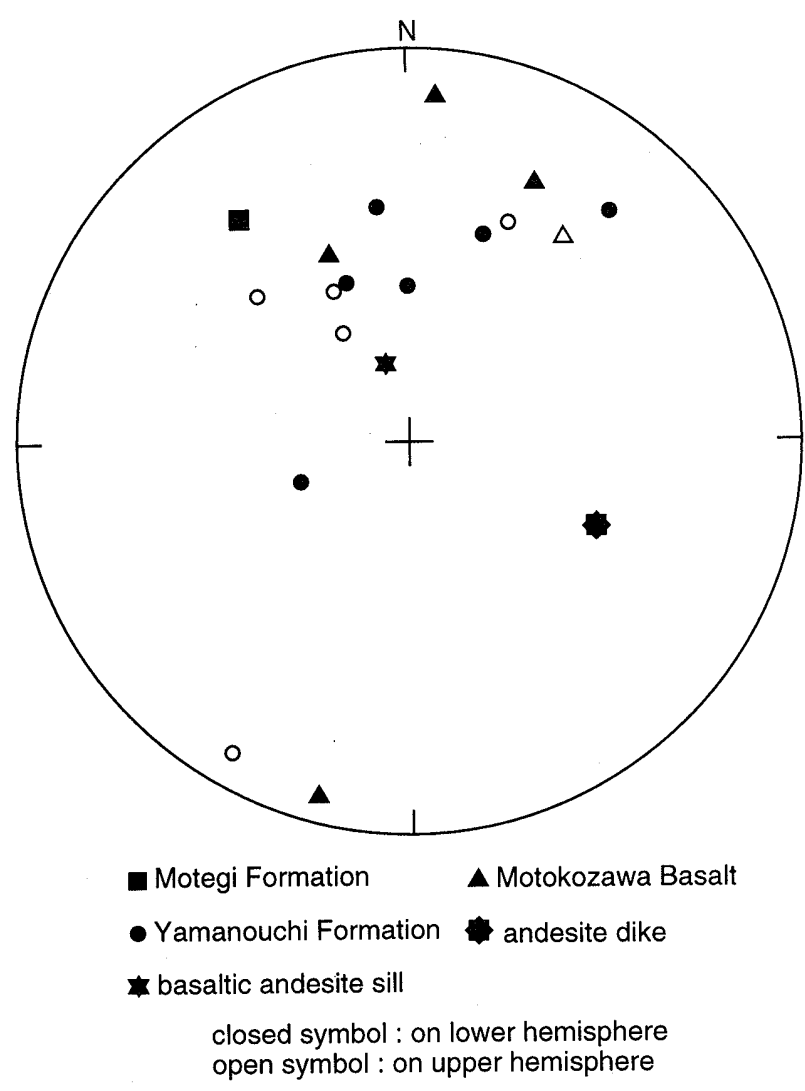

Fig. 5. Directions of magnetization components with low unblocking spectra of Type B magnetization with least squares analyses. Each point is computed using vector endpoints displaying univectorial trend during early steps of thermal demagnetization. Equal-area projection in the geographical coordinates. Most of the directions fall close to the present geomagnetic field direction, suggesting a recently acquired thermoviscous remanent magnetization (see text).

oriented by magnetic reading. One to six specimens were cut from each core sample, yielding more than 350 core samples gathered from 64 sites. We avoided collecting samples from locally disrupted areas. For the basis of tilt correction, we measured the bedding: planes of fine-grained sedimentary and tuff layers.

Measurements of remanent magnetization were carried out using a Natsuhara-Giken SMM-86 spinner magnetometer housed at the Geological Survey of Japan. At least four pilot specimens per site were chosen for detailed progressive demagnetization experiments, one thermally, and the other through the alternating magnetic field method. Progressive alternating field demagnetization (PAFD) was carried out stepwise, up to $100 \mathrm{mT}$ in a three-layer mu-metal shield. Progressive thermal demagnetization (PThD) was performed in more than 12 stages up to $650^{\circ} \mathrm{C}$. The specimens were heated in air using a noninductively wound electric furnace. The results were then used to determine the demagnetization procedures and levels for the remaining specimens.

\section{Paleomagnetism}

\section{Progressive demagnetization}

\subsection{Types of magnetization}

A wide range of behavior was observed during progressive demagnetization. Three main types (A, $\mathrm{B}$ and $\mathrm{C}$ ) were commonly recognized on orthogonal plots (Fig. 4). Types A and B provide records of the paleofields during Early Miocene cooling, while Type $\mathrm{C}$ yields no record of Early Miocene fields.

Type A magnetization is characterized by stable endpoints on stereographic projections, and linear decay to the origin on orthogonal plots ( $\mathrm{A}$ and $\mathrm{B}$ in Fig. 4). It generally has median destructive temperature (MDT) higher than $400^{\circ} \mathrm{C}$, at which the natural remanent magnetization (NRM) intensity is reduced by $50 \%$. The median destructive field (MDF), the alternating field which destroys $50 \%$ of the NRM, is as high as $15 \mathrm{mT}$. Small viscous remanent magnetization (VRM) components can easily be removed during the first few steps. The stable linear components are regarded as the characteristic components of the specimens.

Type $\mathrm{B}$ magnetization is distinguished by two or more distinct components ( $\mathrm{C}$ and $\mathrm{D}$ in Fig. 4). The MDT is generally higher than $350^{\circ} \mathrm{C}$, and MDF is as high as $10 \mathrm{mT}$. Low-coercivity magnetization is removed by treatment at about $20 \mathrm{mT}$ or $400^{\circ} \mathrm{C}$. At higher fields or temperatures, magnetization decays linearly to the origin on orthogonal plots. We regard these stable linear components as characteristics of the specimens.

Type C magnetization is highly variable. It generally has MDT lower than $330^{\circ} \mathrm{C}$, and MDF as low as 7.5 $\mathrm{mT}$. Stable linear components cannot be detected on orthogonal plots (E and F in Fig. 4). Six sites (SK 12, NK 8, NK 10, NK 12, NK 24, and YA 11) yielded specimens belonging to this type.

\subsection{Low-temperature components}

Low-temperature components were recognized in many Type $\mathrm{B}$ specimens. Most of the components were unblocked by $280^{\circ} \mathrm{C}$ through PThD. In order to examine their origin, we determined their directions using the least square analysis technique (Kirschvink, 1980). Components with obvious linearity (maximum angular deviation, MAD, less than $10^{\circ}$ ) were resolved from 22 specimens, and their directions are shown in Fig. 5. Most of the directions fall close to the present geomagnetic field direction $\left(D=-7.0^{\circ} . I=\right.$ $\left.49.8^{\circ}\right)$ and also to the geocentric axial dipole field direction $\left(I=56.0^{\circ}\right)$ expected at the latitude of the study area. These lines of evidence suggest that the low-temperature magnetization component resides in single-domain magnetite and is due to a recent thermoviscous remanent magnetization (TVRM) acquired during the Brunhes normal polarity chron (Chron C1n) (Pullaiash et al., 1975; Walton, 1980 ; 
Kent, 1985), after tectonic stratal tilting.

\subsection{Routine demagnetization for remaining specimens}

We rejected the six sites which had Type $\mathrm{C}$ specimens from the site-mean direction calculations, because stable characteristic components could not be determined. On the other hand, for the 58 sites which provided specimens of Types A and B, both PAFD and PThD treatments effectively erased overprinting VRM, and yielded characteristic components with high stability. Therefore, routine demagnetization for all remaining specimens was conducted by alternating field technique. The demagnetization level for the remaining specimens in each site was based on the following procedures; (1) comparing three orthogonal PAFD plots, (2) selecting a minimum demagnetization level which gives a vector endpoint furthest from the origin on the stable linear trajectory, and then, (3) setting the level one or two steps higher than the minimum level for the routine demagnetization (Hoshi and Takahashi, 1996 b).

\section{Results}

The site-mean paleomagnetic directions calculated from sample-mean directions are listed in Table 1. Three sites (SK 3, SK 4, and SK 11) were rejected due to a lack of reliable tilt correction data. All site-mean directions are shown in Figs. 6 and 7, and Fig. 8 plots the stereographic projections.

\subsection{Motegi Formation}

Basalt and andesite lava flows from 11 sites provided reliable paleomagnetic records. NRM intensities range from 1.64 to $0.27 \mathrm{~A} / \mathrm{m}$. All sites had reversed magnetization. Values of the radius of the $95 \%$ confidence circle $\left(\alpha_{95}\right.$; Fisher, 1953) are less than $6^{\circ}$ for the site means, as well as for every core sample, indicating homogeneous magnetization. Many sites attest to south-seeking paleomagnetic declinations with moderate (about $-50^{\circ}$ ) inclinations, whereas a few denote southeastward or southwestward declinations (Fig. 8). A formation-mean direction calculated from tilt-corrected site-mean directions from 11 sites is $D=$ $-171.6^{\circ}$ and $I=-55.0^{\circ}$ with $\alpha_{95}=9.1^{\circ}$.

\subsection{Yamanouchi Formation}

Thirty-six reliable site-mean directions were obtained from basalt and andesite lava flows with both normal and reversed polarities (Fig. 8). NRM intensities mark wide variations ranging from 3.00 to $0.28 \mathrm{~A} / \mathrm{m}$. The $\alpha_{95}$ values were generally less than $7^{\circ}$ for the site-means, indicating homogeneous magnetization. Many sites register south- or north-seeking declinations with moderate inclinations, except for a few anomalous directions (e.g., NK 13, NK 14 and NK 23 ; Fig. 8). Inverting the normal polarity directions to the reversed one, a time-averaged formationmean direction of $D=-170.1^{\circ}$ and $I=-56.5^{\circ}$ with $\alpha_{95}$ $=4.7^{\circ}$ was derived from the tilt-corrected site-mean directions from 36 sites.

\subsection{Basaltic andesite sills}

Site-mean directions with small $\alpha_{95}$ values $\left(<5^{\circ}\right)$ were obtained from 5 sites. NRM intensities range from 1.77 to $0.88 \mathrm{~A} / \mathrm{m}$. In particular, basaltic andesite sills which crop out in the Motokozawa area, Motegi Town, are characterized by northeastward to eastward declinations with normal polarity (YA 3, YA9 and YA 10 ; Fig. 7). It seems that this is not the result of tilting by local structural disturbances because no obvious changes in geologic structure are observed around the sites. The mean direction for these sills was not calculated.

\subsection{Motokozawa Basalt}

Non-porphyritic basalt sills from 25 sites provided reliable paleomagnetic directions with small $\alpha_{95}$ values (less than $7^{\circ}$ except KS 22). Most of the sills have NRM intensities greater than $2 \mathrm{~A} / \mathrm{m}$, higher than the other formations in the Nakagawa Group. All sites display south-seeking declinations with negative inclinations after tilt-correction (Figs. 7 and 8), strongly suggesting that there has been no tectonic rotation about a vertical axis since emplacement (about $18 \mathrm{Ma}$ ). A mean direction of $D=-179.7^{\circ}$ and $I=-48.3^{\circ}$ with $\alpha_{95}=3.4^{\circ}$ was obtained for these sills from the tilt-corrected site-mean directions.

\subsection{Dikes}

Dikes which intruded into various horizons of the Nakagawa Group were sampled, and 4 sites yielded site-mean paleomagnetic directions. They indicate both normal and reversed polarities, and diverse NRM intensities ranging from 4.73 to $0.37 \mathrm{~A} / \mathrm{m}$. The mean direction was not calculated because the age of the intrusions is unknown.

\section{Field tests of paleomagnetic stability}

Here we describe the results of a reversals test, and prove that the remanent magnetization directions in the volcanic rocks of the Nakagawa Group must represent Early Miocene paleofield directions. If the mean direction computed from the normal-polarity sites is antipodal to the mean direction for the reversed-polarity sites, each characteristic direction is said to "pass the reversals test" (Cox and Doell, 1960; McElhinny, 1973 ; McFadden and McElhinny, 1990 ; Butler, 1992). All tilt-corrected site-mean directions listed in Table 1 are displayed in Fig. 9. The mean direction from 67 reversed-polarity sites $\left(D=-172.8^{\circ}\right.$, $\left.I=-54.3^{\circ}, \alpha_{95}=3.1^{\circ}\right)$ is antipodal to the mean of 14 normal-polarity sites $\left(D=15.5^{\circ}, I=49.4^{\circ}, \alpha_{95}=12.4^{\circ}\right)$. This suggests strongly that the site-means are free of secondary magnetic overprints and that the time sampling afforded by the set of paleomagnetic data has an adequately averaged geomagnetic secular variation. Taking a positive result of a conglomerate test (Hoshi and Takahashi, 1995) into consideration, field tests of paleomagnetic stability allow us to conclude that the remanent magnetization directions obtained are of primary origin. 
Table 1. Paleomagnetic data from the Motegi area.

\begin{tabular}{|c|c|c|c|c|c|c|c|c|c|c|}
\hline & & & in situ & & & tilt cor & rected & & & VGP position \\
\hline Site & $\mathrm{N}$ & Demag. & Decl. $\left(^{\circ}\right)$ Incl. $\left(^{\circ}\right)$ & $\mathrm{Jn}(\mathrm{A} / \mathrm{m})$ & Strike and dip & $\operatorname{Decl}\left(\left(^{\circ}\right)\right.$ & Incl. $\left({ }^{\circ}\right)$ & $\alpha_{95}\left({ }^{\circ}\right)$ & $k$ & lat. long \\
\hline
\end{tabular}

$\begin{array}{lllr}\text { SK2 } & 6 & 15 \mathrm{mT} & 164.1 \\ \text { SK3 } & 6 & 30 \mathrm{mT} & 174.0 \\ \text { SK4 } & 7 & 7.5 \mathrm{mT} & 171.2 \\ \text { SK7 } & 6 & 25 \mathrm{mT} & 160.4 \\ \text { SK9 } & 8 & 20 \mathrm{mT} & 167.6 \\ \text { SK11 } & 8 & 20 \mathrm{mT} & 164.5 \\ \text { SK13 } & 6 & 10 \mathrm{mT} & -173.1 \\ \text { SK14 } & 6 & 20 \mathrm{mT} & -176.5 \\ \text { SK15 } & 5 & 30 \mathrm{mT} & -173.4 \\ \text { SK16 } & 7 & 30 \mathrm{mT} & -156.9 \\ \text { NK1 } & 4 & 10 \mathrm{mT} & -148.6 \\ \text { NK2 } & 6 & 10 \mathrm{mT} & -166.8 \\ \text { NK5 } & 6 & 25 \mathrm{mT} & -177.4 \\ \text { NK11 } & 6 & 20 \mathrm{mT} & 159.3\end{array}$

Andesite and basalt lavas in the Motegi Formation

$\begin{array}{rccrrrrrr}-53.4 & 0.49 & \text { in situ } & 164.1 & -53.4 & 1.6 & 1695.6 & 76.8^{\circ} \mathrm{S} & 136.6^{\circ} \mathrm{W} \\ -56.5 & 0.53 & ? & - & - & 1.3 & 2675.6 & - & - \\ -54.3 & 0.69 & ? & - & - & 4.5 & 180.6 & - & - \\ -52.8 & 1.53 & \text { in situ } & 160.4 & -52.8 & 5.5 & 149.8 & 73.7^{\circ} \mathrm{S} & 135.3^{\circ} \mathrm{W} \\ -62.8 & 0.63 & \text { N7E10E } & -172.3 & -64.5 & 2.7 & 422.8 & 78.7^{\circ} \mathrm{S} & 11.7^{\circ} \mathrm{W} \\ -52.7 & 0.36 & ? & - & - & 2.8 & 393.4 & - & - \\ -59.5 & 0.79 & \text { in situ } & -173.1 & -59.5 & 4.2 & 252.9 & 83.4^{\circ} \mathrm{S} & 13.3^{\circ} \mathrm{E} \\ -55.0 & 0.86 & \text { in situ } & -176.5 & -55.0 & 2.2 & 916.8 & 87.0^{\circ} \mathrm{S} & 69.5^{\circ} \mathrm{E} \\ -56.8 & 1.32 & \text { in situ } & -173.4 & -56.8 & 3.4 & 510.4 & 84.7^{\circ} \mathrm{S} & 39.5^{\circ} \mathrm{E} \\ -31.2 & 0.27 & \text { in situ } & -156.9 & -31.2 & 3.4 & 307.3 & 61.6^{\circ} \mathrm{S} & 88.0^{\circ} \mathrm{E} \\ -38.5 & 1.64 & \text { N43E15S } & -136.3 & -39.9 & 5.3 & 306.6 & 50.0^{\circ} \mathrm{S} & 58.0^{\circ} \mathrm{E} \\ -45.3 & 1.07 & \text { N43E15S } & -151.1 & -51.0 & 2.7 & 631.4 & 65.7^{\circ} \mathrm{S} & 53.3^{\circ} \mathrm{E} \\ -45.4 & 0.94 & \text { N88W22S } & -176.9 & -67.4 & 2.5 & 714.4 & 76.2^{\circ} \mathrm{S} & 31.5^{\circ} \mathrm{W} \\ -37.0 & 0.49 & \text { N55E18S } & 164.7 & -54.2 & 3.1 & 456.2 & 77.5^{\circ} \mathrm{S} & 133.6^{\circ} \mathrm{W}\end{array}$

\begin{tabular}{|c|c|c|c|c|c|c|c|c|c|c|c|c|}
\hline \multicolumn{13}{|c|}{ 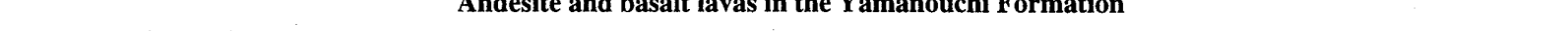 } \\
\hline SK1 & 8 & $20 \mathrm{mT}$ & 159.5 & -57.8 & 0.45 & in situ & 159.5 & -57.8 & 3.2 & 295.5 & $73.7^{\circ} \mathrm{S}$ & $117.1^{\circ} \mathrm{W}$ \\
\hline SK5 & 7 & $10 \mathrm{mT}$ & 159.3 & -54.2 & 0.52 & N43E9S & 166.5 & -62.0 & 4.1 & 216.3 & $77.7^{\circ} \mathrm{S}$ & $92.7^{\circ} \mathrm{W}$ \\
\hline SK6 & 8 & $10 \mathrm{mT}$ & 150.6 & -53.4 & 0.68 & $\mathrm{~N} 45 \mathrm{E} 12 \mathrm{~S}$ & 157.1 & -64.8 & 2.7 & 410.7 & $70.2^{\circ} \mathrm{S}$ & $91.9^{\circ} \mathrm{W}$ \\
\hline SK8 & 8 & $15 \mathrm{mT}$ & 169.3 & -57.0 & 0.51 & in situ & 169.3 & -57.0 & 2.3 & 571.0 & $81.4^{\circ} \mathrm{S}$ & $119.8^{\circ} \mathrm{W}$ \\
\hline SK10 & 4 & $25 \mathrm{mT}$ & 131.7 & -46.4 & 3.00 & $\mathrm{~N} 45 \mathrm{E} 12 \mathrm{E}$ & 130.7 & -58.4 & 6.1 & 224.9 & $51.4^{\circ} \mathrm{S}$ & $110.7^{\circ} \mathrm{W}$ \\
\hline $\mathrm{KS} 2 *$ & 6 & $25 \mathrm{mT}$ & 171.1 & -37.4 & 0.98 & N48E18E & -177.7 & -51.6 & 6.3 & 113.1 & $85.3^{\circ} \mathrm{S}$ & $116.4^{\circ} \mathrm{E}$ \\
\hline $\mathrm{KS} 3 * *$ & 6 & $35 \mathrm{mT}$ & -177.7 & -37.7 & 0.31 & N63E24S & -161.6 & -57.1 & 6.8 & 97.4 & $75.3^{\circ} \mathrm{S}$ & $40.4^{\circ} \mathrm{E}$ \\
\hline KS4** & 7 & $20 \mathrm{mT}$ & 175.1 & -36.4 & 0.69 & N63E24S & -172.5 & -57.7 & 3.9 & 235.9 & $83.8^{\circ} \mathrm{S}$ & $31.3^{\circ} \mathrm{E}$ \\
\hline $\mathrm{KS} 5^{* *}$ & 6 & $15 \mathrm{mT}$ & -166.4 & -41.7 & 0.47 & N63E24S & -144.0 & -57.0 & 5.4 & 153.2 & $61.4^{\circ} \mathrm{S}$ & $37.2^{\circ} \mathrm{E}$ \\
\hline KS6* & 5 & $15 \mathrm{mT}$ & -177.8 & -40.4 & 0.39 & N4IE18E & -162.1 & -49.8 & 6.7 & 130.2 & $74.0^{\circ} \mathrm{S}$ & $66.9^{\circ} \mathrm{E}$ \\
\hline $\mathrm{KS} 8 * *$ & 7 & $10 \mathrm{mT}$ & -8.3 & 52.6 & 1.85 & $\mathrm{~N} 28 \mathrm{E} 18 \mathrm{E}$ & 16.8 & 60.1 & 6.7 & 81.9 & $76.2^{\circ} \mathrm{N}$ & $153.5^{\circ} \mathrm{W}$ \\
\hline KS9** & 6 & $15 \mathrm{mT}$ & -4.3 & 45.9 & 2.39 & $\mathrm{~N} 28 \mathrm{E} 18 \mathrm{E}$ & 15.4 & 52.9 & 5.1 & 172.7 & $77.1^{\circ} \mathrm{N}$ & $120.6^{\circ} \mathrm{W}$ \\
\hline KS10** & 7 & $15 \mathrm{mT}$ & -8.7 & 40.8 & 1.62 & $\mathrm{~N} 20 \mathrm{E} 22 \mathrm{E}$ & 12.1 & 47.9 & 3.1 & 378.1 & $77.3^{\circ} \mathrm{N}$ & $96.4^{\circ} \mathrm{W}$ \\
\hline $\mathrm{KS} 11^{* *}$ & 7 & $15 \mathrm{mT}$ & -28.6 & 38.3 & 0.83 & N41E27E & -12.8 & 62.4 & 1.8 & 1092.7 & $77.9^{\circ} \mathrm{N}$ & $90.3^{\circ} \mathrm{E}$ \\
\hline KS13** & 6 & $35 \mathrm{mT}$ & -9.0 & 25.4 & 0.94 & N34E22E & 2.1 & 38.9 & 5.5 & 147.4 & $75.3^{\circ} \mathrm{N}$ & $47.7^{\circ} \mathrm{W}$ \\
\hline KS16 & 5 & $10 \mathrm{mT}$ & -173.5 & -49.2 & 1.31 & N26E29E & -138.0 & -50.2 & 2.2 & 1195.0 & $54.9^{\circ} \mathrm{S}$ & $46.9^{\circ} \mathrm{E}$ \\
\hline KS17 & 4 & $20 \mathrm{mT}$ & 179.7 & -42.3 & 1.26 & $\mathrm{~N} 26 \mathrm{E} 29 \mathrm{E}$ & -150.6 & -48.4 & 6.2 & 223.2 & $64.4^{\circ} \mathrm{S}$ & $58.0^{\circ} \mathrm{E}$ \\
\hline NK3 & 6 & $15 \mathrm{mT}$ & -161.1 & -48.5 & 0.56 & in situ & -161.1 & -48.5 & 3.0 & 499.2 & $72.7^{\circ} \mathrm{S}$ & $68.9^{\circ} \mathrm{E}$ \\
\hline NK4 & 6 & $25 \mathrm{mT}$ & -126.6 & -67.8 & 0.51 & in situ & -126.6 & -67.8 & 3.3 & 424.7 & $49.9^{\circ} \mathrm{S}$ & $12.1^{\circ} \mathrm{E}$ \\
\hline NK13** & 7 & $20 \mathrm{mT}$ & 160.7 & -69.8 & 1.63 & N55E18S & -140.6 & -84.4 & 2.2 & 770.1 & $44.7^{\circ} \mathrm{S}$ & $30.0^{\circ} \mathrm{W}$ \\
\hline NK $14 * *$ & 6 & $20 \mathrm{mT}$ & 155.3 & -70.8 & 1.29 & $\mathrm{~N} 55 \mathrm{E} 18 \mathrm{~S}$ & -140.1 & -86.5 & 2.8 & 585.0 & $41.8^{\circ} \mathrm{S}$ & $33.9^{\circ} \mathrm{W}$ \\
\hline NK15** & 5 & $10 \mathrm{mT}$ & 163.9 & -57.3 & 1.94 & N28E19E & -163.9 & -66.6 & 16.8 & 21.8 & $72.8^{\circ} \mathrm{S}$ & $2.0^{\circ} \mathrm{W}$ \\
\hline NK $16^{* *}$ & 6 & $15 \mathrm{mT}$ & -5.2 & 34.6 & 0.83 & $\mathrm{~N} 28 \mathrm{E} 19 \mathrm{E}$ & 8.7 & 43.1 & 1.6 & 1718.4 & $76.3^{\circ} \mathrm{N}$ & $75.2^{\circ} \mathrm{W}$ \\
\hline NK17** & 6 & $10 \mathrm{mT}$ & 178.5 & -37.9 & 1.96 & N52E30S & -155.3 & -58.1 & 6.3 & 112.9 & $70.4^{\circ} \mathrm{S}$ & $36.2^{\circ} \mathrm{E}$ \\
\hline NK $18^{* *}$ & 6 & $15 \mathrm{mT}$ & 178.2 & -26.5 & 0.74 & N52E30S & -165.3 & -48.4 & 6.6 & 105.2 & $75.7^{\circ} \mathrm{S}$ & $76.3^{\circ} \mathrm{E}$ \\
\hline NK19** & 6 & $15 \mathrm{mT}$ & 172.9 & -35.3 & 1.00 & N53E30S & -165.5 & -58.7 & 2.4 & 765.8 & $78.3^{\circ} \mathrm{S}$ & $31.9^{\circ} \mathrm{E}$ \\
\hline NK20** & 5 & $15 \mathrm{mT}$ & -0.9 & 5.2 & 2.76 & N75E46S & 6.8 & 49.3 & 3.1 & 606.9 & $81.4^{\circ} \mathrm{N}$ & $83.3^{\circ} \mathrm{W}$ \\
\hline NK21 ** & 6 & $20 \mathrm{mT}$ & 162.8 & -27.0 & 0.28 & N63E24S & 166.8 & -50.5 & 2.5 & 707.7 & $77.8^{\circ} \mathrm{S}$ & $151.9^{\circ} \mathrm{W}$ \\
\hline NK22** & 5 & $10 \mathrm{mT}$ & -172.7 & -30.9 & 1.20 & N63E24S & -159.2 & -49.2 & 2.0 & 1401.1 & $71.5^{\circ} \mathrm{S}$ & $64.6^{\circ} \mathrm{E}$ \\
\hline NK23** & 5 & $15 \mathrm{mT}$ & -4.5 & -2.7 & 2.08 & N63E24S & -3.1 & 19.4 & 2.9 & 697.3 & $63.3^{\circ} \mathrm{S}$ & $33.1^{\circ} \mathrm{W}$ \\
\hline NK25** & 5 & $20 \mathrm{mT}$ & 173.3 & -23.3 & 1.53 & N43E33S & -169.1 & -45.5 & 3.4 & 516.4 & $76.6^{\circ} \mathrm{S}$ & $93.1^{\circ} \mathrm{E}$ \\
\hline NK26 & 5 & $20 \mathrm{mT}$ & 173.5 & -44.5 & 1.29 & N30E21S & -164.2 & -53.7 & 6.7 & 131.0 & $76.9^{\circ} \mathrm{S}$ & $55.6^{\circ} \mathrm{E}$ \\
\hline NK27 & 4 & $15 \mathrm{mT}$ & 177.4 & -49.9 & 0.38 & N30E21S & -155.2 & -57.0 & 6.6 & 192.7 & $70.3^{\circ} \mathrm{S}$ & $39.8^{\circ} \mathrm{E}$ \\
\hline
\end{tabular}


Table 1. (continued)

\begin{tabular}{|c|c|c|c|c|c|c|c|c|c|c|c|c|}
\hline \multirow[b]{2}{*}{ Site } & \multirow[b]{2}{*}{$\mathrm{N}$} & \multirow[b]{2}{*}{ Demag. } & \multicolumn{2}{|c|}{ in situ } & \multirow[b]{2}{*}{$\mathrm{Jn}(\mathrm{A} / \mathrm{m})$} & \multirow[b]{2}{*}{ Strike and dip } & \multicolumn{2}{|c|}{ tilt corrected } & \multirow[b]{2}{*}{$\alpha_{95}\left(^{\circ}\right)$} & \multirow[b]{2}{*}{$k$} & \multicolumn{2}{|c|}{ VGP position } \\
\hline & & & $\operatorname{Decl} .\left(^{\circ}\right)$ & Incl. $\left(^{\circ}\right)$ & & & $\operatorname{Decl} .\left(^{\circ}\right)$ & Incl. $\left(^{\circ}\right)$ & & & lat. & long. \\
\hline NK28 & 6 & $10 \mathrm{mT}$ & 169.7 & -50.2 & 1.15 & N41E24E & -158.8 & -64.8 & 3.6 & 350.3 & $71.2^{\circ} \mathrm{S}$ & 10. \\
\hline NK29 & 5 & $20 \mathrm{mT}$ & 172.4 & -52.0 & 2.48 & N29E7E & -179.5 & -55.8 & 4.5 & 286.7 & $89.5^{\circ} \mathrm{S}$ & \\
\hline NK30 & 5 & $15 \mathrm{mT}$ & -173.6 & -31.7 & 0.30 & N53E15S & -165.3 & -41.9 & 5.8 & 174.5 & $72.3^{\circ} \mathrm{S}$ & 90 \\
\hline
\end{tabular}

$\begin{array}{lll}\text { KS1 } & 6 & 10 \mathrm{mT} \\ \text { KS24 } & 6 & 20 \mathrm{mT} \\ \text { YA3 } & 7 & 25 \mathrm{mT} \\ \text { YA9 } & 5 & 20 \mathrm{mT} \\ \text { YA10 } & 5 & 20 \mathrm{mT}\end{array}$

Basaltic andesite sills intruding the Motokozawa Formation

$\begin{array}{rrrcrrrrrr}-12.4 & 19.3 & 1.35 & \text { N13E29E } & 0.2 & 29.0 & 3.5 & 376.5 & 68.9^{\circ} \mathrm{N} & 40.3^{\circ} \mathrm{W} \\ -22.2 & 31.9 & 1.66 & \text { N4E22E } & -7.1 & 39.1 & 2.9 & 537.2 & 74.3^{\circ} \mathrm{N} & 14.8^{\circ} \mathrm{W} \\ 62.9 & 79.8 & 0.88 & \text { N33W26E } & 58.8 & 53.8 & 1.6 & 1340.3 & 42.9^{\circ} \mathrm{N} & 145.5^{\circ} \mathrm{W} \\ 114.4 & 57.6 & 1.77 & \text { N2W18E } & 106.4 & 40.9 & 2.7 & 788.7 & 1.7^{\circ} \mathrm{N} & 158.1^{\circ} \mathrm{W} \\ 55.8 & 76.8 & 1.44 & \text { N33W26E } & 56.6 & 50.8 & 4.2 & 329.1 & 43.5^{\circ} \mathrm{N} & 140.9^{\circ} \mathrm{W}\end{array}$

\begin{tabular}{|c|c|c|c|c|c|c|c|c|c|c|c|c|}
\hline \multicolumn{13}{|c|}{ Motokozawa Basalt (Non-porphyritic basalt sills) } \\
\hline KS12 & 6 & $35 \mathrm{mT}$ & 164.5 & -19.9 & 3.37 & N58E26S & 170.0 & -44.5 & 3.1 & 479.7 & $76.6^{\circ} \mathrm{S}$ & $177.7^{\circ} \mathrm{W}$ \\
\hline $\mathrm{KS} 14 * *$ & 6 & $30 \mathrm{mT}$ & 164.5 & -24.6 & 4.51 & N47E29S & 176.8 & -49.0 & 2.0 & 1095.9 & $82.8^{\circ} \mathrm{S}$ & $162.9^{\circ} \mathrm{E}$ \\
\hline KS15 & 7 & $10 \mathrm{mT}$ & 153.8 & -45.6 & 3.15 & N31E28E & -174.9 & -65.1 & 4.0 & 228.2 & $78.8^{\circ} \mathrm{S}$ & $21.6^{\circ} \mathrm{W}$ \\
\hline $\mathrm{KS} 18^{* *}$ & 5 & $7.5 \mathrm{mT}$ & 162.2 & -33.9 & 4.34 & N43E22S & 174.2 & -52.1 & 4.2 & 336.9 & $83.8^{\circ} \mathrm{S}$ & $167.4^{\circ} \mathrm{W}$ \\
\hline KS 19 & 5 & $25 \mathrm{mT}$ & 160.8 & -29.0 & 5.20 & N43E22S & 170.3 & -47.7 & 3.6 & 454.6 & $78.7^{\circ} \mathrm{S}$ & $170.9^{\circ} \mathrm{W}$ \\
\hline KS20 & 4 & $20 \mathrm{mT}$ & 159.6 & -30.8 & 1.30 & N53E26S & 168.5 & -55.2 & 3.6 & 641.9 & $80.6^{\circ} \mathrm{S}$ & $131.6^{\circ} \mathrm{W}$ \\
\hline $\mathrm{KS} 21$ & 4 & $25 \mathrm{mT}$ & 176.8 & 0.7 & 2.59 & N59E27S & 179.4 & -23.0 & 6.6 & 197.6 & $65.4^{\circ} \mathrm{S}$ & $141.5^{\circ} \mathrm{E}$ \\
\hline $\mathrm{KS} 22$ & 4 & $25 \mathrm{mT}$ & -179.1 & -14.1 & 3.18 & N59E27S & -171.6 & -36.2 & 10.2 & 82.9 & $72.0^{\circ} \mathrm{S}$ & $113.7^{\circ} \mathrm{E}$ \\
\hline $\mathrm{KS} 23 * *$ & 5 & $10 \mathrm{mT}$ & 173.3 & -28.4 & 4.05 & N47E34S & -164.7 & -52.3 & 4.9 & 244.4 & $76.9^{\circ} \mathrm{S}$ & $62.2^{\circ} \mathrm{E}$ \\
\hline YA1 & 6 & $15 \mathrm{mT}$ & 160.0 & -51.8 & 4.95 & N15W14E & 177.6 & -50.9 & 2.6 & 641.2 & $84.6^{\circ} \mathrm{S}$ & $162.4^{\circ} \mathrm{E}$ \\
\hline YA4 & 5 & $15 \mathrm{mT}$ & 149.0 & -59.5 & 1.06 & N37W26E & -176.9 & -48.7 & 1.8 & 1818.1 & $82.6^{\circ} \mathrm{S}$ & $118.6^{\circ} \mathrm{E}$ \\
\hline YA5 & 4 & $15 \mathrm{mT}$ & 147.7 & -60.9 & 1.86 & N37W26E & -176.2 & -50.2 & 3.5 & 690.3 & $83.5^{\circ} \mathrm{S}$ & $109.6^{\circ} \mathrm{E}$ \\
\hline YA6 & 6 & $15 \mathrm{mT}$ & 169.6 & -57.1 & 2.68 & N6E17E & -163.3 & -58.0 & 4.9 & 191.7 & $76.6^{\circ} \mathrm{S}$ & $36.3^{\circ} \mathrm{E}$ \\
\hline YA7 & 6 & $30 \mathrm{mT}$ & 167.5 & -50.6 & 4.66 & N11W16E & -173.7 & -48.4 & 3.2 & 426.8 & $81.1^{\circ} \mathrm{S}$ & $102.4^{\circ} \mathrm{E}$ \\
\hline YA8 & 5 & $15 \mathrm{mT}$ & 161.9 & -37.6 & 1.06 & N2E22E & -179.8 & -41.9 & 1.6 & 2428.7 & $77.6^{\circ} \mathrm{S}$ & $139.5^{\circ} \mathrm{E}$ \\
\hline YA12 & 5 & $15 \mathrm{mT}$ & 170.7 & -37.4 & 2.23 & $\mathrm{~N} 18 \mathrm{E} 18 \mathrm{E}$ & -174.7 & -43.6 & 1.6 & 2173.2 & $78.0^{\circ} \mathrm{S}$ & $116.4^{\circ} \mathrm{E}$ \\
\hline YA13 & 5 & $20 \mathrm{mT}$ & 175.5 & -25.4 & 2.95 & $\mathrm{~N} 45 \mathrm{E} 28 \mathrm{E}$ & -169.6 & -44.5 & 4.2 & 334.2 & $76.4^{\circ} \mathrm{S}$ & $96.9^{\circ} \mathrm{E}$ \\
\hline YA14 & 6 & $15 \mathrm{mT}$ & 165.9 & -52.3 & 3.91 & N23W19E & -173.1 & -45.8 & 2.0 & 1135.7 & $79.0^{\circ} \mathrm{S}$ & $106.3^{\circ} \mathrm{E}$ \\
\hline YA15 & 5 & $15 \mathrm{mT}$ & 162.6 & -45.8 & 2.16 & N23W19E & -179.8 & -41.0 & 1.6 & 2371.0 & $76.9^{\circ} \mathrm{S}$ & $139.3^{\circ} \mathrm{E}$ \\
\hline YA16 & 5 & $15 \mathrm{mT}$ & 161.2 & -46.1 & 2.48 & N23W19E & 179.2 & -41.7 & 1.3 & 3634.6 & $77.4^{\circ} \mathrm{S}$ & $143.4^{\circ} \mathrm{E}$ \\
\hline YA17 & 5 & $15 \mathrm{mT}$ & 153.8 & -52.0 & 4.84 & N15W14E & 172.0 & -52.5 & 2.4 & 1004.6 & $82.6^{\circ} \mathrm{S}$ & $155.5^{\circ} \mathrm{W}$ \\
\hline YA18 & 4 & $10 \mathrm{mT}$ & 161.0 & -48.9 & 2.99 & N15W14E & 176.9 & -47.9 & 1.8 & 2691.5 & $82.0^{\circ} \mathrm{S}$ & $160.1^{\circ} \mathrm{E}$ \\
\hline YA19 & 4 & $15 \mathrm{mT}$ & 157.8 & -50.6 & 1.94 & N15W14E & 174.9 & -50.3 & 2.6 & 1233.1 & $83.0^{\circ} \mathrm{S}$ & $179.1^{\circ} \mathrm{E}$ \\
\hline YA20 & 5 & $10 \mathrm{mT}$ & 148.6 & -54.4 & 4.61 & N15W14E & 168.8 & -56.0 & 1.3 & 3650.4 & $81.0^{\circ} \mathrm{S}$ & $126.9^{\circ} \mathrm{W}$ \\
\hline YA21 & 5 & $10 \mathrm{mT}$ & 156.0 & -55.8 & 4.24 & N15W14E & 176.7 & -55.5 & 2.8 & 767.1 & $87.3^{\circ} \mathrm{S}$ & $141.1^{\circ} \mathrm{W}$ \\
\hline
\end{tabular}

\begin{tabular}{lllrrrrrrrrrr}
\multicolumn{10}{c}{ Basalt and andesite dikes } \\
DK1 & 5 & $10 \mathrm{mT}$ & -159.4 & -57.7 & 2.01 & in situ & -159.4 & -57.7 & 3.5 & 485.3 & $73.6^{\circ} \mathrm{S}$ & $37.8^{\circ} \mathrm{E}$ \\
NK31 & 4 & $20 \mathrm{mT}$ & -167.1 & -22.5 & 2.25 & N66E31S & -152.2 & -45.1 & 3.9 & 548.6 & $64.4^{\circ} \mathrm{S}$ & $65.0^{\circ} \mathrm{E}$ \\
NK32 & 4 & $10 \mathrm{mT}$ & -156.2 & -39.9 & 4.73 & N66E31S & -125.1 & -54.6 & 11.0 & 70.9 & $46.1^{\circ} \mathrm{S}$ & $34.9^{\circ} \mathrm{E}$ \\
NK33 & 6 & $15 \mathrm{mT}$ & -2.7 & 15.9 & 0.37 & N66E31S & 5.1 & 44.1 & 7.9 & 73.5 & $78.4^{\circ} \mathrm{N}$ & $63.5^{\circ} \mathrm{W}$ \\
\hline
\end{tabular}

$\mathrm{N}=$ number of core samples. Demag. = demagnetization level. Decl. and Incl. = site-mean paleomagnetic declination and inclination. $\mathrm{J}_{\mathrm{n}}=$ intensity of NRM. $\alpha_{95}=$ radius of $95 \%$ confidence circle. $k=$ precision parameter. lat. and long. = latitude and longitude. *: Hoshi and Takahashi (1995). **: Hoshi and Takahashi (1996b). 


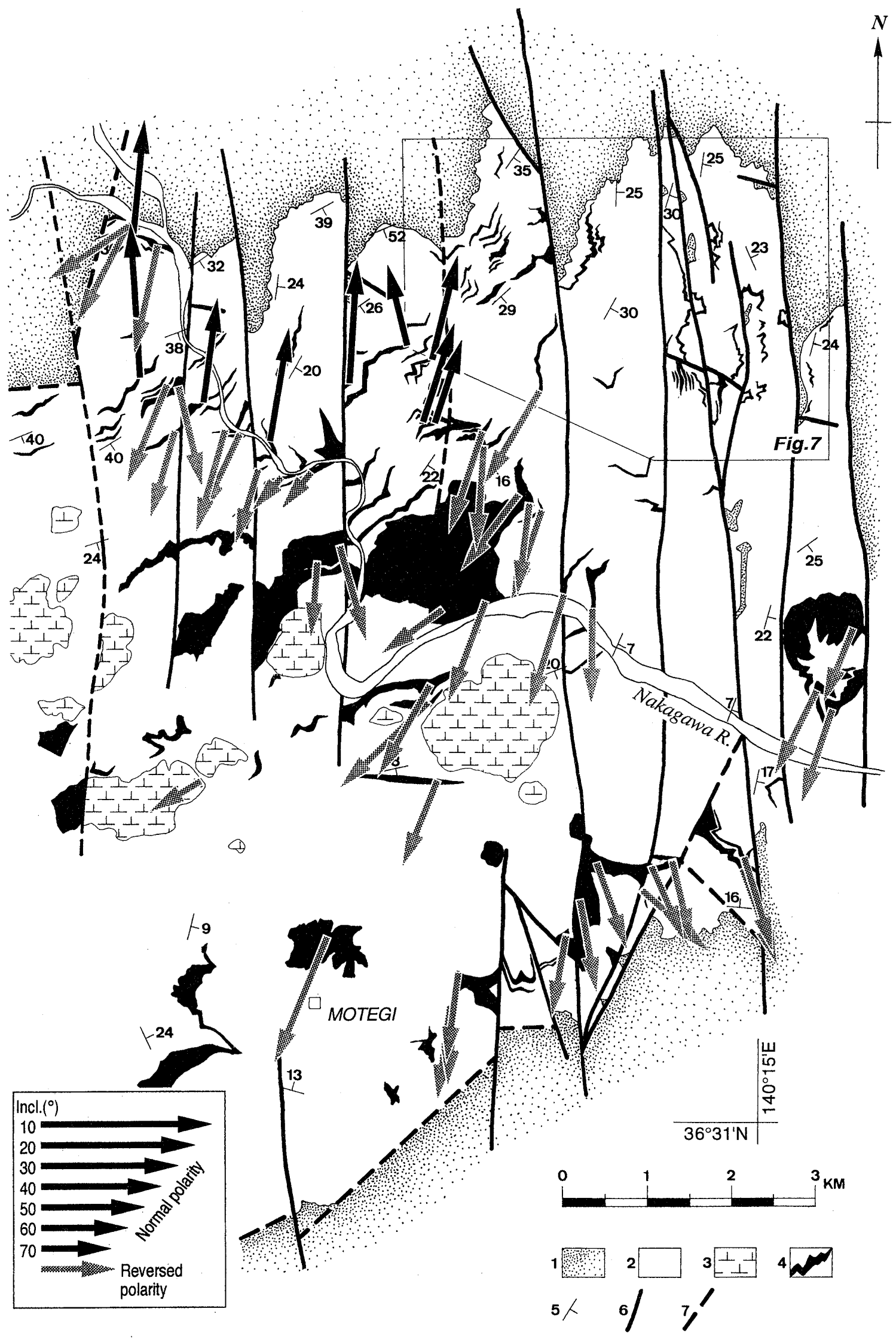

Fig. 6. Tilt-corrected paleomagnetic directions of Early Miocene volcanic rocks in the Motegi area. 1:preTertiary basement rocks. $2:$ sedimentary and volcaniclastic rocks. $3:$ dacite. $4:$ basalt and andesite. $5:$ strike and dip of strata. $6:$ fault. $7:$ inferred fault. 


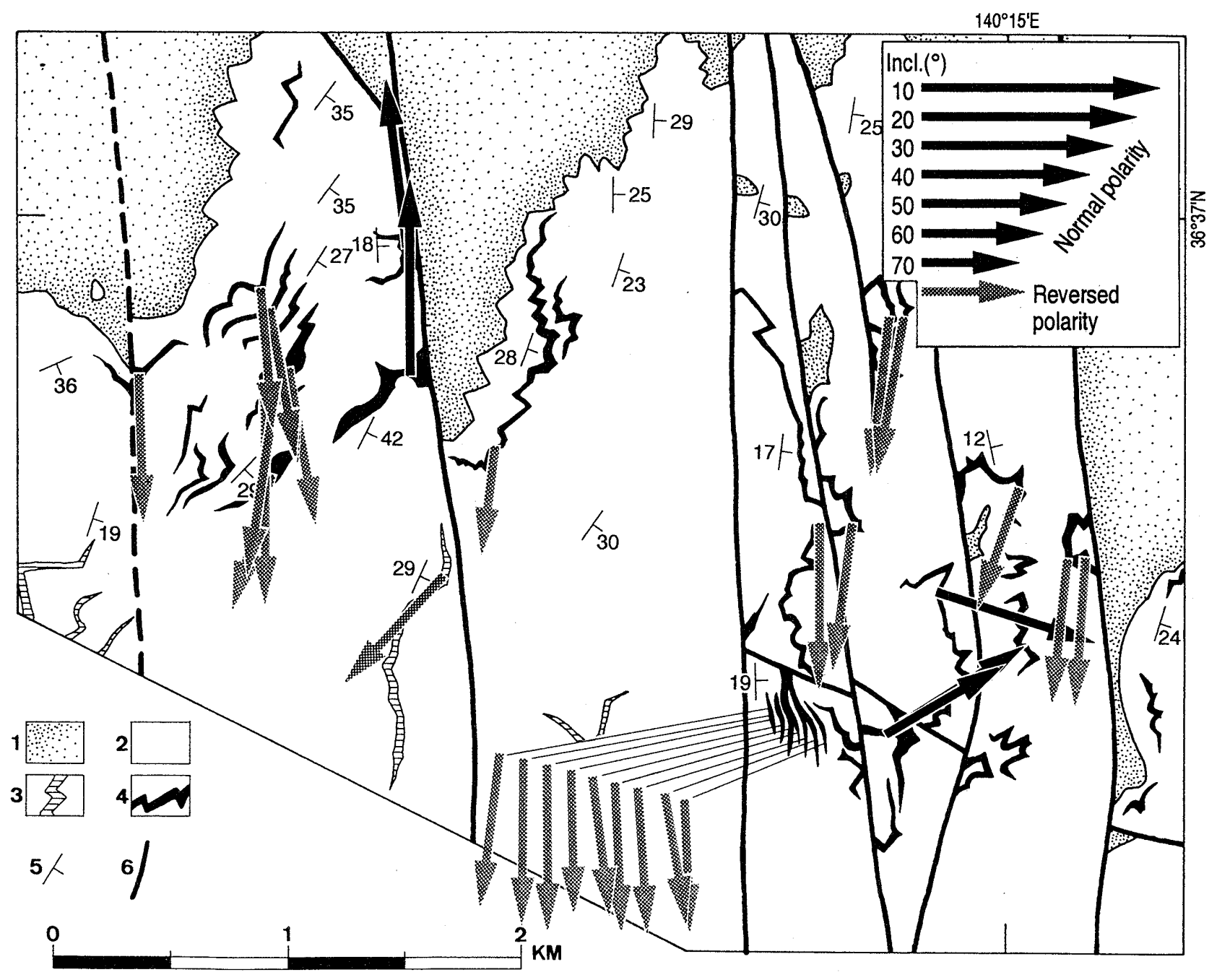

Fig. 7. Tilt-corrected paleomagnetic directions of volcanic rocks in the northeastern part of the Motegi area. 1 : pre-Tertiary basement. 2 : sedimentary and volcaniclastic rocks. $3:$ basalt and andesite lava. 4 : basalt and andesite sill. $5:$ strike and dip of strata. $6:$ fault.

\section{Discussion}

\section{Rotation of the Motegi area}

The mean paleomagnetic direction of the Motokozawa Basalt, as well as lava flows in the Motegi and Yamanouchi Formations, displays no deflected declination (Table 2), suggesting no rotational motion about a vertical axis. Since the age of intrusion of the Motokozawa Basalt is estimated to be $18 \mathrm{Ma}$, we consider that the study area has not suffered vertical-axis rotation since $18 \mathrm{Ma}$.

To quantitatively determine the amount of rotation in the study area since $18 \mathrm{Ma}$, we calculated the amount of rotation with respect to the North China Block (NCB) in the Asian continent for each depositional (or intrusive) stage of the formations. This was achieved through a comparison of observed and expected declination values. We used the paleomagnetic data of Zhao et al. (1994) to compute the expected geomagnetic field directions at the representative point in the study area $\left(36.6^{\circ} \mathrm{N}, 140.2^{\circ} \mathrm{E}\right)$.
Zhao et al. (1994) reported that the Tertiary paleomagnetic pole position for the NCB was $86.3^{\circ} \mathrm{N}$ and $159.9^{\circ} \mathrm{W}$, with $95 \%$ confidence limit, $A_{95}=5.9^{\circ}$, and stated that the NCB is in the same position today as it was during the Tertiary.

According to Beck (1980), the amount of verticalaxis rotation, $R$, is given as $D_{\mathrm{ob}}-D_{\mathrm{ex}}$, where $D_{\mathrm{ob}}$ and $D_{\mathrm{ex}}$ are the observed and expected declinations, respectively. $R$ is defined as positive when $D_{\mathrm{ob}}$ is clockwise of $D_{\text {ex }}$. The confidence limit of $R, d R$, is $\left(d D_{\mathrm{ob}}{ }^{2}+d D_{\mathrm{ex}}{ }^{2}\right.$ )$^{1 / 2}$, where $d D_{\mathrm{ob}}$, the confidence limit of $D_{\mathrm{ob}}$, and $d D_{\mathrm{ex}}$, the confidence limit of $D_{\text {ex }}$, can be determined from the equations, $d D_{\mathrm{ob}}=\sin ^{-1}\left(\sin \alpha_{95} / \cos I_{\mathrm{ob}}\right)$ and $d D_{\mathrm{ex}}=\sin ^{-1}$ ( $\sin A_{95} / \sin p$ ), where $I_{\mathrm{ob}}$ is the observed inclination, and $p$ is the magnetic colatitude, the great-circle angular distance of the study area from the NCB reference pole position. Values $R$ and $d R$ for three stages are listed in Table 2 and shown in Fig. 10.

Rotation estimates for three stages lead us to conclude that the Motegi area has not undergone vertical-axis rotation since $18 \mathrm{Ma}$. An average for 11 site- 

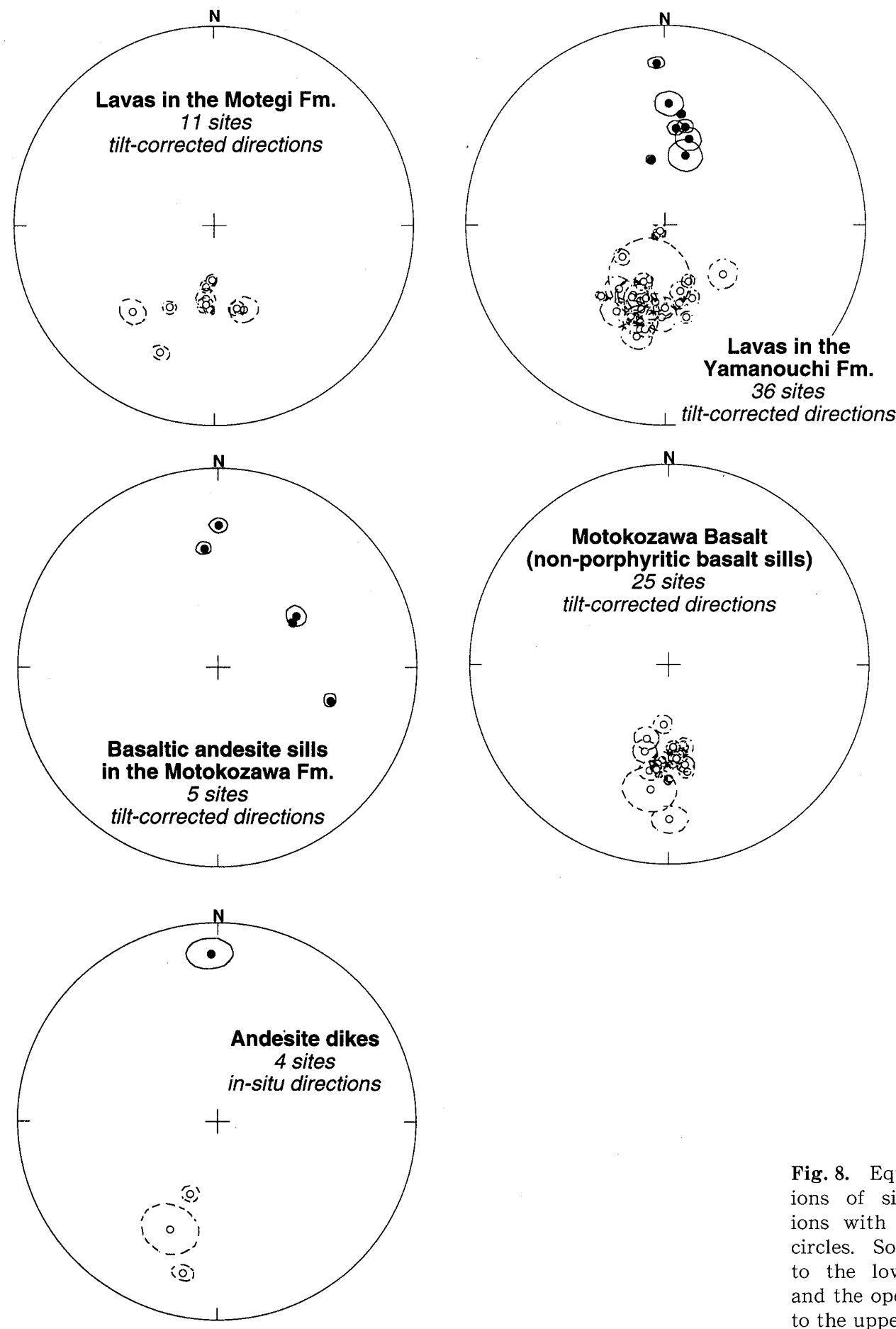

Fig. 8. Equal-area projections of site-mean directions with $95 \%$ confidence circles. Solid symbols refer to the lower hemisphere, and the open symbols refer to the upper hemisphere.

mean directions from the Motegi Formation indicates vertical-axis rotation of $4.3 \pm 17.7^{\circ}$, suggesting little rotation after the deposition of the formation. A rotation parameter for 36 sites from the Yamanouchi Formation shows vertical-axis rotation of only $5.8 \pm$ $11.3^{\circ}$, which is similar to the average Motegi Formation. The Motokozawa Basalt, the oldest volcanic unit in the study area, also indicates little rotation $\left(-3.8 \pm 9.1^{\circ}\right)$ after its emplacement $(18 \mathrm{Ma})$. Therefore, it is obvious that little rotational motion has occurred in the study area since $18 \mathrm{Ma}$.

\section{Regional extent of rotated (or unrotated)} blocks

2.1. Spatial and temporal distribution of paleomagnetic directions

Kitakami Mountains

Yamazaki (1989) measured the paleomagnetism of sedimentary rocks in the Matsushima area (Fig. 1), near the southern border of the Kitakami Mountains, and revealed that the lower Middle Miocene Matsushima and Otsuka Formations showed no deflected declinations. Yamazaki (1989) also detected 
a magnetostratigraphic polarity-reversal horizon just above the Matsushima/Otsuka Formation boundary, which is correlative to the Chron C $5 \mathrm{Cn} / \mathrm{C} 5 \mathrm{Br}$ boundary (16.014 Ma: Cande and Kent, 1995). This data indicates that no rotational motion has occurred in the Matsushima area since $16 \mathrm{Ma}$.

A paleomagnetic study in the Ninohe area (Fig. 1) of the northwestern margin of the Kitakami Mountains was performed by Hayashida (1994a). Hayashida (1994 a) showed that the area was subjected to a large $\left(\sim 70^{\circ}\right)$ counter-clockwise rotation between the deposition of the Nisatai Dacite (22-21 Ma : Tagami et al., 1995) and the Kadonosawa Formation (about $16 \mathrm{Ma}$ : Irizuki and Matsubara, 1994, and references therein). The Kadonosawa Formation has northerly declinations, indicating no rotation since $16 \mathrm{Ma}$.

Recent air-borne and ship-borne surveys have revealed remarkable features in magnetic intensity anomalies in and around Japan (e.g., Okubo et al., 1994). A north-south, magnetic intensity anomaly belt running from Matsushima to the southern part of Hokkaido (Segawa and Oshima, 1975 ; Finn, 1994 ; Okubo et al., 1994) (Fig. 11) is considered to result from a Cretaceous batholith, $120-70 \mathrm{~km}$ wide and at least 15 $-10 \mathrm{~km}$ thick (Finn, 1994). Because the anomaly is coherent, the implication is that the block containing the batholith has been a single unit since the Cretaceous. Therefore, considering the paleomagnetic results (Yamazaki, 1989 ; Hayashida, 1994 a) as well as the implication from the magnetic anomaly belt, the Kitakami Mountains (perhaps also southern Hokkaido) are considered to have suffered counterclockwise rotation between 22 and $16 \mathrm{Ma}$ as a single unit, and have been stationary since $16 \mathrm{Ma}$.

\section{Kanto Mountains}

Hyodo and Niitsuma (1986) collected 16-15 Ma sedimentary rocks from the Chichibu Basin in the Kanto Mountains (Fig. 1) and obtained reliable magnetic remanences from 11 sites. The time-averaged mean direction exhibits easterly deflected declination $(D=$ $93.7^{\circ}$ ), indicating a large clockwise rotation of the Kanto Mountains since $15 \mathrm{Ma}$. Takahashi and Nomura (1989) measured the paleomagnetism of the Chichibu Quartz Diorite (about 6Ma: Ueno and Shibata, 1986 ; Saito et al., 1996), and their results indicate no rotational motion of the mountains from $6 \mathrm{Ma}$. This, therefore, implies that the Kanto Mountains were subjected to large $\left(\sim 90^{\circ}\right)$ clockwise rotation between 15 and $6 \mathrm{Ma}$.

\subsection{Extent of rigid blocks and their boundaries}

As described in previous sections, the Motegi area has not suffered vertical-axis rotation since $18 \mathrm{Ma}$, and the Kitakami Mountains also have not rotated since $16 \mathrm{Ma}$. These facts indicate that no relative rotation has occurred between the block containing the Motegi and the Kitakami Mountains since at least $16 \mathrm{Ma}$. We interpret these two blocks to have

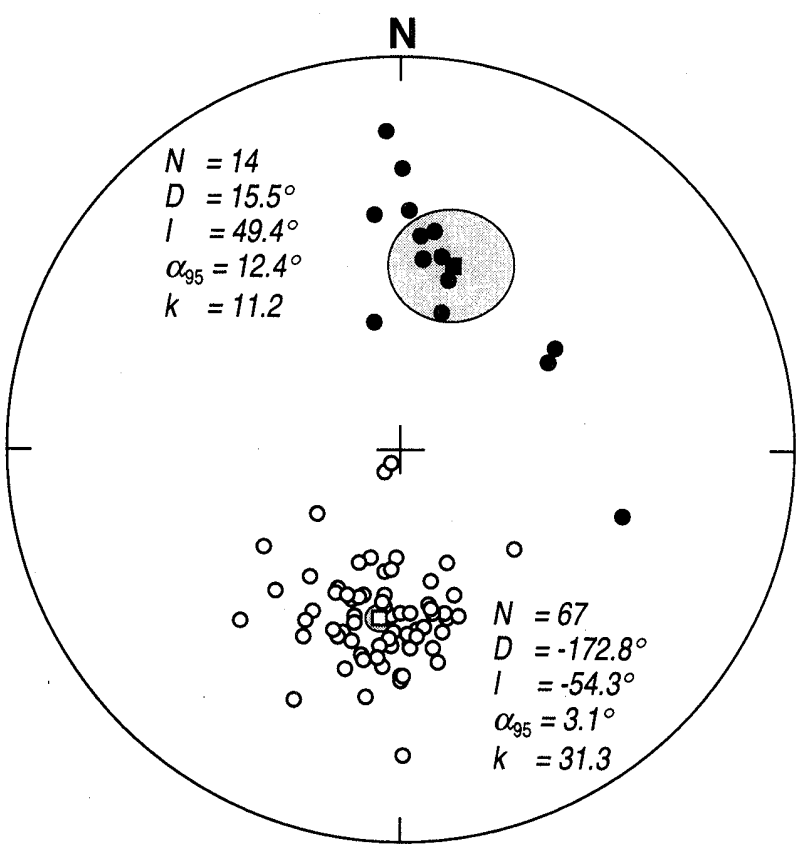

Fig. 9. Site-mean directions of lava flows in the Motegi and Yamanouchi Formations and the Motokozawa Basalt, having overall mean directions for formations with normal and reversed polarities. The mean direction from reversed-polarity sites is antiparallel to the mean direction of normal-polarity sites, representing a positive reversals test. Equalarea projections with solid symbols on the lower hemisphere and open symbols on the upper hemisphere. Circles denote site-mean directions; squares and shaded ovals indicate overall means and their $95 \%$ confidence limit.

behaved, kinematically, as a single rigid block since 16 Ma. The interpreted single block, provisionally called "the Frontal Block of the Northern Honshu; FBNH", is approximately $500 \mathrm{~km}$ long, extending from the Motegi to the Ninohe areas (Fig. 11).

The above interpretation is also supported by structural data. In northern Honshu, we can recognize several shear zones trending NNW-SSE (Fig. 1). In the region between the Motegi and the Kitakami Mountains, the Tanakura, Hatakawa and Futaba Shear Zones run almost parallel to each other. Leftlateral displacement on these shear zones commenced in the Cretaceous (Otsuki and Ehiro, 1978, 1992). Leftlateral displacements for the Tanakura, Hatakawa and Futaba Shear Zones are estimated to be $>240 \mathrm{~km}$, $60 \mathrm{~km}$ and $130 \mathrm{~km}$, respectively (Otsuki and Ehiro, 1992). No geologic data suggesting large displacement in the Miocene has been reported to date (e.g., Otsuki and Ehiro, 1978 ; Koshiya, 1986), supporting our interpretation. It is noted that any marked kinematic boundaries which possess the ability to rotate microblocks differentially have not occurred within the FBNH since $16 \mathrm{Ma}$.

In contrast, the Kanto Mountains have suffered large clockwise rotation between 15 and $6 \mathrm{Ma}$ 
Table 2. Time-averaged mean paleomagnetic directions and pole positions for each formation. Calculated rotation values relative to the North China Block are also listed.

\begin{tabular}{|c|c|c|c|c|c|c|c|c|}
\hline \multirow{2}{*}{ Formation } & \multirow{2}{*}{$\begin{array}{c}\text { Number } \\
\text { of sites }\end{array}$} & \multirow{2}{*}{$\begin{array}{l}D \\
(9\end{array}$} & \multirow{2}{*}{$\begin{array}{l}I \\
(9)\end{array}$} & \multirow{2}{*}{$\begin{array}{r}\alpha_{95} \\
(9\end{array}$} & \multirow{2}{*}{$\begin{array}{r}R \pm d R \\
(9)\end{array}$} & \multicolumn{3}{|c|}{ North pole position } \\
\hline & & & & & & Lat. & Long. & $\overline{A_{95}}$ \\
\hline Motegi & 11 & -171.6 & -55.0 & 9.1 & $4.3 \pm 17.7$ & $84.2 \mathrm{~N}$ & $229.7^{\circ} \mathrm{E}$ & $10.9^{\circ}$ \\
\hline Yamanouchi & 36 & -170.1 & -56.5 & 4.7 & $5.8 \pm 11.3$ & $81.1 \mathrm{~N}$ & $203.7^{\circ} \mathrm{E}$ & $6.0^{\circ}$ \\
\hline $\begin{array}{l}\text { Motokozawa } \\
\text { Basalt }\end{array}$ & 25 & -179.7 & -48.3 & 3.4 & $-3.8 \pm 9.1$ & $83.3 \mathrm{~N}$ & $318.2 \mathrm{E}$ & $3.4^{\circ}$ \\
\hline
\end{tabular}

$D$ and $I=$ formation-mean paleomagnetic declination and inclination, respectively. $\quad \alpha_{95}=95 \%$ confidence limit of formation-mean direction. $R \pm d R=$ calculated rotation angle relative to the North China Block. Lat. and Long. = latitude and longitude of paleomagnetic pole. $A_{95}=95 \%$ confidence limit of paleomagnetic pole.

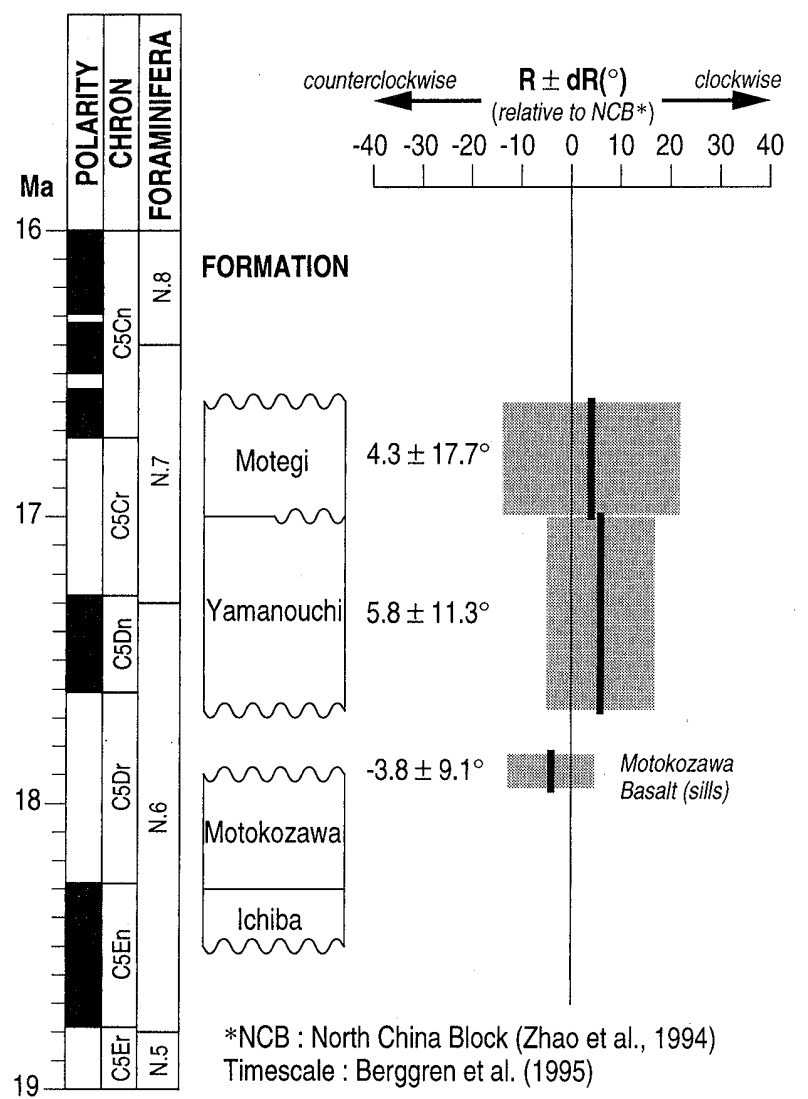

Fig. 10. Rotation with respect to the North China Block versus age for geological units in the Motegi area.

(Takahashi and Nomura, 1989), indicating differential rotation between the $\mathrm{FBNH}$ and the mountains after $15 \mathrm{Ma}$. Takahashi (1994) stated that one half of the overall rotation of the mountains probably occurred at about $15 \mathrm{Ma}$ in association with the rapid clockwise rotation of SW Japan (e.g., Otofuji et al., 1991). The remaining rotation occurred up until $6 \mathrm{Ma}$, resulting in the sharply bent structure of the Kanto Syntaxis, and is probably related to the collision of the IzuBonin Arc with the Japan Arc in central Japan
(Takahashi, 1994). The clockwise rotation of the mountains ceased by $6 \mathrm{Ma}$. It is noted that a profound kinematic boundary must have existed between the FBNH and the Kanto Mountains before 6 $\mathrm{Ma}$.

A possible explanation is that the kinematic block boundary was the Kanto Tectonic Line (KTL: Kobayashi and Otuka, 1938). Kobayashi and Otuka (1938) discussed basement geologic structures in and around the Kanto district and postulated a rightlateral fault, the KTL, between the Ashio and Kanto Mountains. Although the proposed KTL is currently buried under the Kanto Plain, its existence has been proven by gravity and seismic methods (e.g., Ishii, 1962 ; Komazawa and Hasegawa, 1988). We interpret the KTL to be the pre- $6 \mathrm{Ma}$ block boundary between the FBNH and the Kanto Mountains (Fig. 11).

Although the FBNH has behaved as a coherent rigid block since at least $16 \mathrm{Ma}$, it seems to have comprised two or more blocks before that time. As described above, the Kitakami Mountains are considered to have experienced large $\left(\sim 70^{\circ}\right)$ counter-clockwise rotation in a period between 22 and $16 \mathrm{Ma}$. Paleomagnetic results from the Abukuma Mountains (Hirooka et al., 1986), however, imply less rotation during Early Miocene time. Four andesite dikes in the Abukuma Mountains, yielding $\mathrm{K}-\mathrm{Ar}$ ages of 23-21 Ma (Tsunakawa et al., 1983), provide a mean paleomagnetic direction of $D=-14.3^{\circ}, I=52.8^{\circ}$ and $\alpha_{95}=8.2^{\circ}$ (calculated using data from sites ND 22, ND 23, ND 26 and ND27 of Hirooka et al., 1986). An estimate of vertical-axis rotation with respect to the $\mathrm{NCB}$ is -18.4 $\pm 15.6^{\circ}$ (the representative point in the mountains $=$ $37.4^{\circ} \mathrm{N}, 140.6^{\circ} \mathrm{E}$ ), suggesting small counter-clockwise rotation after $21 \mathrm{Ma}$. This implies differential rotation within the FBNH in the Early Miocene; the amount of the counter-clockwise rotation of the Kitakami Mountains was larger than that of the Abukuma Mountains.

3. Timing of rotation of NE Japan

Our conclusions imply little rotational motion of NE 
Japan since $16 \mathrm{Ma}$, contradicting the claim of Otofuji et al. (1994). Otofuji et al. (1994) concluded that northern Honshu and southwest Hokkaido, the region from latitudes $38^{\circ} \mathrm{N}$ to $43^{\circ} \mathrm{N}$, rotated counter-clockwise at about $15 \mathrm{Ma}$ as a single rigid block. However, several paleomagnetic studies show results discordant with the claim. For example, Tanaka et al. (1991) point out, based on paleomagnetic results in the Shakotan Peninsula (Fig. 1), that the Peninsula has not undergone rotation since $15 \mathrm{Ma}$. Preliminary results of paleomagnetic measurements performed in the Yamagata area (Hoshi et al., 1992) are also discordant with the $15 \mathrm{Ma}$ rotation. Likewise, Tosha and Hamano (1988) reported magnetic measurement results for rocks in the Oga Peninsula, and concluded that a counter-clockwise rotation occurred between 22 and $15 \mathrm{Ma}$. Therefore, we have suspicions that the counter-clockwise rotation of NE Japan occurred before $15 \mathrm{Ma}$. Further high reliability paleomagnetic and chronological studies are required to clarify the timing of the counter-clockwise rotation.

\section{Conclusions}

1. Paleomagnetic investigations were conducted in the Motegi area to quantitatively estimate the amount of rotation with respect to the Asian continent. As a result, it was clarified that the area has not suffered vertical-axis rotation since $18 \mathrm{Ma}$.

2. Since the Motegi, Matsushima and Ninohe areas preserve indistinguishable north-south seeking paleomagnetic directions, it is clear that relative rotation has not occurred among these areas since $16 \mathrm{Ma}$. Thus, we conclude that, since $16 \mathrm{Ma}$, the frontal region of northern Honshu was kinematically composed of a single rigid block (the FBNH). However, an Early Miocene rotation estimate from the Abukuma Mountains differs markedly from that from the Kitakami Mountains. This suggests differential rotation within the FBNH in Early Miocene time ; the amount of the counter-clockwise rotation of the Kitakami Mountains being larger than that of the Abukuma Mountains.

3. Although the FBNH has not suffered verticalaxis rotation from at least $16 \mathrm{Ma}$, the Kanto Mountains have experienced a large $\left(\sim 90^{\circ}\right)$ clockwise rotation between 15 and $6 \mathrm{Ma}$. Consequently, we conclude that the southern kinematic limit of the rigid FBNH in the period between 15 and $6 \mathrm{Ma}$ has been the Kanto Tectonic Line.

4. Taking our results and also previously reported paleomagnetic data into account, it is suggested that the counter-clockwise rotation of NE Japan had already ended by $15 \mathrm{Ma}$. However, further paleomagnetic and chronological investigations of Tertiary rocks in the Japan Arc are required.

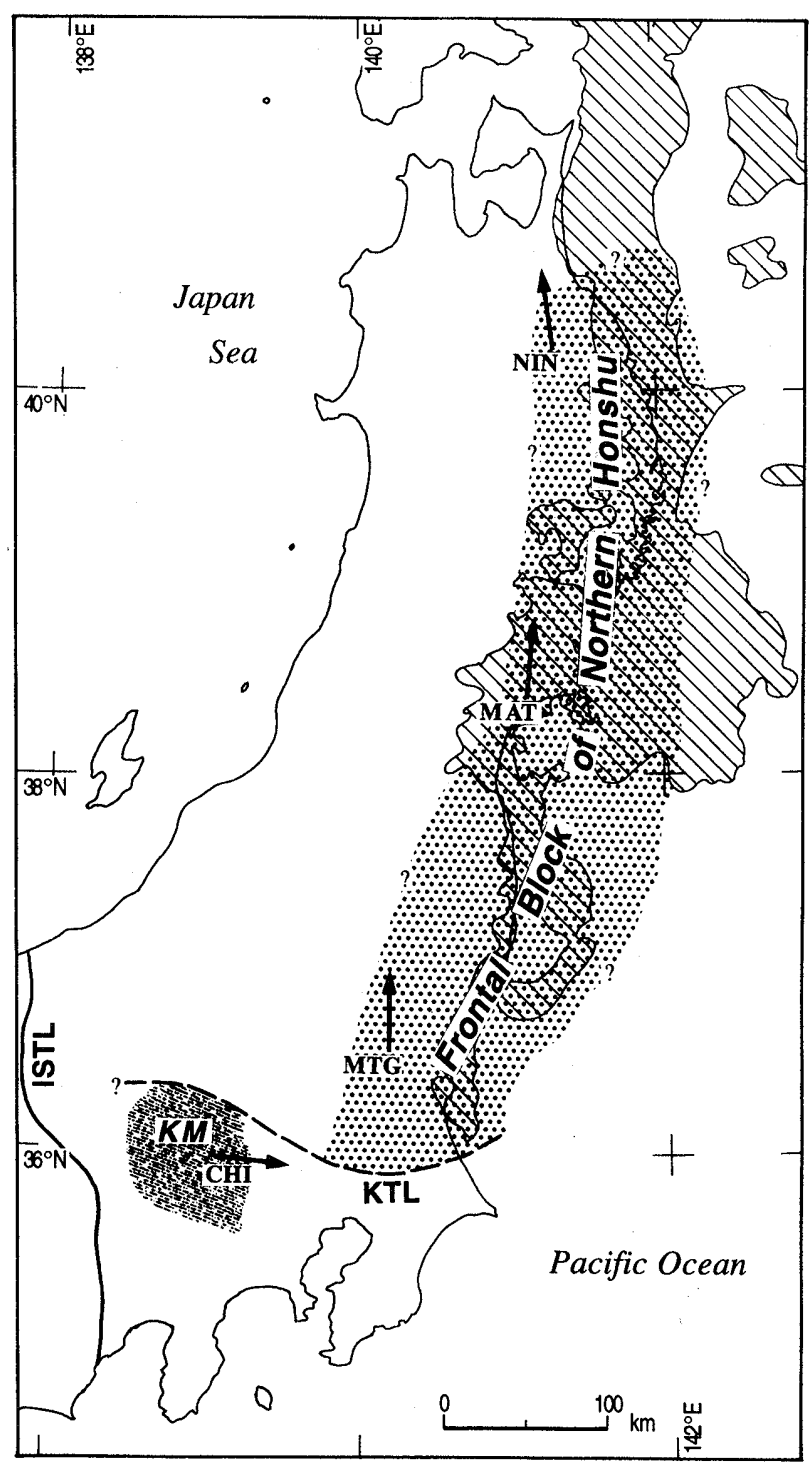

Fig. 11. Schematic diagram illustrating the areal extent of the "Frontal Block of Northern Honshu: FBNH". The FBNH is approximately $500 \mathrm{~km}$ long, extending from the Kanto Tectonic Line (KTL; Kobayashi and Otuka, 1938) to the Ninohe area (NIN). Arrows indicate the paleomagnetic declinations of late Early Miocene rocks. A positive magnetic anomaly belt (Segawa and Oshima, 1975: oblique-line area) is clearly recognized from the Matsushima area (MAT) to the southern part of Hokkaido (off the figure). CHI : Chichibu Basin. MTG : Motegi area. ISTL : ItoigawaShizuoka Tectonic Line.

\section{Acknowledgements}

We are indebted to Y. Otofuji (Kobe University) for his valuable information on computer programs and for encouragement. Measurements of remanent magnetization were performed at the Department of Marine Geology, Geological Survey of Japan, Tsukuba, with generous supervision of T. Yamazaki and $H$. Kanaya. Special thanks go to M. Usami (Kumamoto University) for his help in the field. We 
would like to thank anonymous reviewers for critical comments on an earlier version. The first author $(H$. H.) expresses deep appreciation to T. Nakada and her family, who provided various conveniences during a long stay in Tsukuba.

\section{References}

Amano, K., 1991, Multiple collision tectonics of the South Fossa Magna in central Japan. Modern Geol., 15, 315-329.

Beck, M.E., Jr., 1980, Paleomagnetic record of plate-margin tectonic processes along the western edge of North America. Jour. Geophys. Res., 85, 7115-7131.

Berggren, W. A., Kent, D. V., Swisher, C.C. and Aubry, M.P., 1995, A revised Cenozoic geochronology and chronostratigraphy. In Berggren, W.A., Kent, D. V., Aubry, M. P. and Hardenbol, J., eds., Geochronology, time scales and global stratigraphic correlation. SEPM Spec. Pub. No. 54, 129-212.

Burckle, L.H., Brunner, C. A., Alexandrovich, J., DeMenocal, P., Briscoe, J., Hamano, Y., Heusser, L., Ingle, J.C., Jr., Kheradyar, T., Koizumi, I., Krumsiek, K.A.O., Ling, H. Y., Muza, J.P., Rahamn, A., Sturz, A., Vigliotti, L., White, L.D., Wippern, J.J.M. and Yamanoi, T., 1992, Biostratigraphic and biochronologic synthesis of Legs 127 and 128 : Sea of Japan. In Tamaki, K., Suyehiro, K., Allan, J., McWilliams, M. et al., eds., Proc. ODP, Sci. Results, 127/128, Pt. 2, College Station, TX, 1219-1228.

Butler, R.F., 1992, Paleomagnetism : magnetic domains to geologic terranes. Blackwell, Boston, $319 \mathrm{p}$.

Cande, S.C. and Kent, D. V., 1995, Revised calibration of the geomagnetic polarity timescale for the Late Cretaceous and Cenozoic. Jour. Geophys. Res., 100, 6093-6095.

Cox, A. and Doell, R.R., 1960, Review of paleomagnetism. Bull. Geol. Soc. Amer., 71, 645-768.

Finn, C., 1994, Aeromagnetic evidence for a buried Early Cretaceous magmatic arc, northeast Japan. Jour. Geophys. Res., 99, 22165-22185.

Fisher, R., 1953, Dispersion on a sphere. Proc. Roy. Soc. London, Ser. A, 217, 295-305.

Hayashida, A., 1994 a, Paleomagnetic directions of the Kadonosaw a area and the rotation of Northeast Japan. Chikyu Monthly, 16, 135-138.**

Hayashida, A., 1994 b, Paleomagnetism of Miocene sedimentary rocks in the Kakegawa area and implication for tectonic rotation in central Japan. Jour. Geomag. Geoelectr., 46, 1051-1066.

Hirooka, K., Sakai, H., Takahashi, T., Kinoto, H. and Takeuchi, A., 1986, Tertiary tectonic movement of central Japan inferred from paleomagnetic studies. Jour. Geomag. Geoelectr., 38, 311-323.

Hirooka, K., Yamada, R., Yamashita, M. and Takeuchi, A., 1990, Paleomagnetic evidence of the rotation of central Japan and the paleoposition of Japan. Palaeogeogr. Palaeoclimatol. Palaeoecol., 77, 345-354.

Hoshi, H. and Otsuki, K., 1996, Reconstruction of the Early to Middle Miocene stress fields in the Motegi area, Northeast Japan, using minor fault analyses. Jour. Geol. Soc. Japan, 102, 700-714.*

Hoshi, H. and Takahashi, M., 1995, Primary magnetization of the Early Miocene volcanic rocks in the Motegi area, Tochigi Prefecture, central Japan - paleomagnetic conglomerate test-. Bull. Geol. Surv. Japan, 46, 537-553.*

Hoshi, H. and Takahashi, M., 1996 a, Stratigraphy and geologic structure of the Lower Miocene in the Motegi area : The relationship between $\mathrm{N}-\mathrm{S}$ trending fault activity and tectonics in Miocene Northeast Japan. Jour. Geol. Soc. Japan, 102, 25-39.*
Hoshi, H. and Takahashi, M., 1996 b, Magnetostratigraphy of the Early to Middle Miocene volcanic sequence in the Motegi area, Northeast Japan, and the time of volcanic activity. Jour. Geol. Soc. Japan, 102, 573-590.*

Hoshi, H., Takahashi, M. and Saito, K., 1992, Paleomagnetic study of the Miocene Yoshino Formation, Yamagata Prefecture. Rock Mag. Paleogeophys., 19, 38-42.

Hyodo, H. and Niitsuma, N., 1986, Tectonic rotation of the Kanto Mountains, related with the opening of the Japan Sea and collision of the Tanzawa Block since Middle Miocene. Jour. Geomag. Geoelectr., 38, 335-348.

Ingle, J.C., Jr., 1992, Subsidence of the Japan Sea: Stratigraphic evidence from ODP sites and onshore sections. In Tamaki, K., Suyehiro, K., Allan, J., McWilliams, M. et al., eds., Proc. ODP, Sci. Results, 127/ 128, Pt. 2, College Station, TX, 1197-1218.

Irizuki, T. and Matsubara, T., 1994, Vertical changes of depositional environments of the Lower to Middle Miocene Kadonosawa Formation based on analyses of fossil ostracode faunas. Jour. Geol. Soc. Japan, 100, 136149.*

Ishii, M., 1962, Basement of the Kwanto Plain. Jour. Japan. Assoc. Petroleum Tech., 27, 615-640.*

Itoh, Y., 1988, Differential rotation of the eastern part of Southwest Japan inferred from paleomagnetism of Cretaceous and Neogene rocks. Jour. Geophys. Res., 93, 3401-3411.

Itoh, Y. and Ito, Y., 1989, Confined ductile deformation in the Japan arc inferred from paleomagnetic studies. Tectonophysics, 167, 57-73.

Kaneoka, I., 1990, Radiometric age and Sr isotope characteristics of volcanic rocks from the Japan Sea floor. Geochem. Jour., 24, 7-19.

Kaneoka, I., Takigami, Y., Takaoka, N., Yamashita, S. and Tamaki, K., 1992, ${ }^{40} \mathrm{Ar}-{ }^{39} \mathrm{Ar}$ analysis of volcanic rocks recovered from the Japan Sea floor : Constraints on the age of formation of the Japan Sea. In Tamaki, K., Suyehiro, K., Allan, J., McWilliams, M. et al., eds., Proc. $O D P$, Sci. Results, $127 / 128$, Pt. 2, College Station, TX, 819-836.

Kawada, K., 1947, On the Tertiary strata around the Torinoko mountain block, Tochigi Prefecture. Jour. Geol. Soc. Japan, 53, 92.**

Kawada, K., 1953, Geological studies on the Yamizo, Torinoko and Toriashi mountain blocks and their neighborhood in the northeastern Kwanto district. Sci. Rep. Tokyo Bunrika Daigaku, Ser. C, 2, 217-307.

Kent, D. V., 1985, Thermoviscous remagnetization in some Appalachian limestones. Geophys. Res. Lett., 12, 805-808.

Kimura, T., Hayami, I. and Yoshida, S., 1991, Geology of Japan. University of Tokyo Press, Tokyo, $287 \mathrm{p}$.

Kirschvink, J. L., 1980, The least-squares line and plane and the analysis of palaeomagnetic data. Geophys. Jour. Roy. Astr. Soc., 62, 699-718.

Kobayashi, T. and Otuka, Y., 1938, The geologic structure of southwestern Japan and its Mesozoic palaeogeography (Part 7). Jour. Geol. Soc. Japan, 45, 392-400.**

Kodama, K., Takeuchi, T. and Ozawa, T., 1993, Clockwise tectonic rotation of Tertiary sedimentary basins in central Hokkaido, northern Japan. Geology, 21, 431-434.

Komazawa, M. and Hasegawa, I., 1988, The graben structure suggested by the gravimetric basement in the Kanto district, central Japan. Mem. Geol. Soc. Japan, no. 31, 5774.*

Kono, M., 1986, Magnetic anomalies in the Sea of Japan : A speculation on the tectonic history. Jour. Geomag. Geoelectr., 38, 411-426.

Koshiya, S., 1986, Tanakura Shear Zone : The deformation 
process of fault rocks and its kinematics. Jour. Geol. Soc. Japan, 92, 15-29.*

Koyama, A., 1991, Collision of the Kushigatayama block with the Honshu arc during the Middle Miocene. Modern Geol., 15, 331-345.

McElhinny, M. W., 1973, Palaeomagnetism and plate tectonics. Cambridge University Press, London, 358 p.

McFadden, P.L. and McElhinny, M. W., 1990, Classification of the reversal test in palaeomagnetism. Geophys. Jour. Int., 103, 725-729.

Nakasa, Y. and Kinoshita, H., 1994, A supplement to magnetic anomaly of the Japan Basin. Jour. Geomag. Geoelectr., 46, 481-500.

Okubo, Y., Makino, M., Kasuga, S., Isezaki, N., Yamazaki, T., Ishihara, T. and Nakatsuka, T., 1994, Magnetic anomalies of Japan and adjoining areas. Jour. Geomag. Geoelectr., 46, 411-421.

Otofuji, Y., 1996, Large tectonic movement of the Japan Arc in late Cenozoic times inferred from paleomagnetism: Review and synthesis. The Island Arc, 5, 229-249.

Otofuji, Y., Itaya, T. and Matsuda, T., 1991, Rapid rotation of southwest Japan -palaeomagnetism and $\mathrm{K}$-Ar ages of Miocene volcanic rocks of southwest Japan. Geophys. Jour. Int., 105, 397-405.

Otofuji, Y., Kambara, A., Matsuda, T. and Nohda, S., 1994, Counterclockwise rotation of Northeast Japan : Paleomagnetic evidence for regional extent and timing of rotation. Earth. Planet. Sci. Lett., 121, 503-518.

Otsuki, K. and Ehiro, M., 1978, Major strike-slip faults and their bearing on spreading in the Japan Sea. Jour. Phys. Earth, 26, Suppl., 537-555.

Otsuki, K. and Ehiro, M., 1992, Cretaceous left-lateral faulting in Northeast Japan and its bearing on the origin of geologic structure of Japan. Jour. Geol. Soc. Japan, 98, $1097-1112{ }^{*}$

Pouclet, A. and Bellon, H., 1992, Geochemistry and isotopic composition of volcanic rocks from the Yamato Basin : Hole 794 D, Sea of Japan. In Tamaki, K., Suyehiro, K., Allan, J., McWilliams, M. et al., eds., Proc. ODP, Sci. Results, 127/128, Pt. 2, College Station, TX, 779-789.

Pullaiash, G.E., Irving, E., Buchan, K. L. and Dunlop, D.J., 1975. Magnetization changes caused by burial and uplift. Earth Planet. Sci. Lett., 28, 133-143.

Saito, K., Takahashi, M. and Onozuka, N., 1996, A K-Ar investigation of the Chichibu Quartz Diorite and some discussions on its cooling history. Jour. Geomag. Geoelectr., 48, 1103-1109.

Sakai, T., 1986, Lithostratigraphy of Neogene Arakawa Group at the type section (Tochigi Prefecture, Japan). Bull. Fac. General Edu., Utsunomiya Univ., no. 19, 49-70.*

Segawa, J. and Oshima, S., 1975, Buried Mesozoic volcanicplutonic fronts of the north-western Pacific island arcs and their tectonic implications. Nature, 256, 15-19.

Sekine, Y., 1983, Tertiary strata in and around Motegi Town, Tochigi Prefecture. 90th Annual Meeting Geol. Soc. Japan Abstr., 146.**

Shuto, K., Izaki, T. and Yashima, R., 1985, Tertiary $\mathrm{TiO}_{2}$-rich tholeiite from northern part of Motegi district of Tochigi Prefecture, Northeast Japan. Jour. Japan. Assoc. Mineral. Petrol. Econ. Geol., 80, 246-262.*

Suzuki, K., 1989, On the plant biostratigraphy of the Middle to Lower Miocene strata in the southern part of Northeast Honshu Arc, Japan. Mem. Geol. Soc. Japan, no. 32, 197-205.*

Tagami, T., Uto, K., Matsuda, T., Hasebe, N. and Matsumoto, A., 1995, K-Ar biotite and fission-track zircon ages of the Nisatai Dacite, Iwate Prefecture, Japan : A candidate for Tertiary age standard. Geochem. Jour., 29, 207-
211.

Takagi, K., Aoike, K. and Koyama, M., 1993, What happened on the northern tip of the Izu-Bonin Arc during 15-10 Ma? Jour. Geogr., 102, 252-263.*

Takahashi, M., 1994, Miocene lateral bending of central Japan - Intra-arc deformation at arc-arc collision zone -. Bull. Geol. Surv. Japan, 45, 477-495.

Takahashi, M. and Hoshi, H., 1995, Radiometric ages of the Early Miocene volcanic rocks in the Motegi area, Tochigi Prefecture, central Japan. Jour. Geol. Soc. Japan, 101, 821-824.**

Takahashi, M. and Hoshi, H., 1996, Geologic age of the Nakagawa Group in the Motegi area, Tochigi Prefecture and its tectonic significance. Bull. Geol. Surv. Japan, 47, 317-333.*

Takahashi, M. and Nomura, S., 1989, Paleomagnetism of the Chichibu Quartz Diorite - Constraints on the time of lateral bending of the Kanto Syntaxis. Jour. Geomag. Geoelectr., 41, 479-489.

Takahashi, M. and Watanabe, Y., 1993, Paleomagnetism of the Miocene igneous rocks in the Uchiyama area, central Japan. Jour. Geomag. Geoelectr., 45, 89-101.

Tamaki, K., 1986, Age estimation of the Japan Sea on the basis of stratigraphy, basement depth, and heat flow data. Jour. Geomag. Geoelectr., 38, 427-446.

Tamaki, K., 1988, Geological structure of the Japan Sea and its tectonic implications. Bull. Geol. Surv. Japan, 39, 269365.

Tanaka, H., Tsunakawa, H., Yamagishi, H. and Kimura, G., 1991, Paleomagnetism of the Shakotan Peninsula, West Hokkaido, Japan. Jour. Geomag. Geoelectr., 43, 277-294.

Tosha, T. and Hamano, Y., 1988, Paleomagnetism of Tertiary rocks from the Oga Peninsula and the rotation of Northeast Japan. Tectonics, 7, 653-662.

Tsunakawa, H., Takeuchi, A. and Amano, K., 1983, K-Ar ages of dikes in Northeast Japan. Geochem. Jour., 17, $269-275$.

Ueno, H. and Shibata, K., 1986, Radiometric ages of quartz diorite bodies related to the Chichibu pyrometasomatic deposits and their relevance to the metallogenic epoch. Jour. Japan. Assoc. Mineral. Petrol. Econ. Geol., 81, 77-82.

Usami, M., Takahashi, M. and Oda, M., 1995, Planktonic foraminiferal biostratigraphy of Arakawa Group Kobana Formation, Tochigi Prefecture. 102nd Annual Meeting Geol. Soc. Japan Abstr., 137.**

Usami, M., Oda, M. and Takahashi, M., 1996, Planktonic foraminiferal biostratigraphy of the Kobana Formation, Arakawa Group. 103rd Annual Meeting Geol. Soc. Japan Abstr., 144.**

Walton, D., 1980, Time-temperature relations in the magnetization of assemblies of single domain grains. Nature, 286, 245-247.

Yamazaki, T., 1989, Paleomagnetism of Miocene sedimentary rocks around Matsushima Bay, Northeast Japan and its implication for the timing of the rotation of Northeast Japan. Jour. Geomag. Geoelectr., 41, 533-548.

Zhao, X., Coe, R., Zhou, Y., Hu, S., Wu, H., Kuang, G., Dong, Z. and Wang, J., 1994, Tertiary paleomagnetism of North and South China and a reappraisal of late Mesozoic paleomagnetic data from Eurasia : implications for the Cenozoic tectonic history of Asia. Tectonophysics, 235, 181-203.

Zijderveld, J.D.A., 1967, A.C. demagnetization of rocks: Analysis of results. In Collinson, D. W., Creer, K.M. and Runcorn, S.K., eds., Methods in paleomagnetism. Elsevier, Amsterdam, 254-286.

* : in Japanese with English abstract

** : in Japanese 
(要 旨)

Hoshi, H. and Takahashi, M., 1997, Paleomagnetic constraints on the extent of tectonic blocks and the location of their kinematic boundaries : Implications for Miocene intraarc deformation in Northeast Japan. Jour. Geol. Soc. Japan, 103, 523-542.（星 博幸 . 高橋雅紀, 1997, 回転地塊の規模および運動境界の位置に対する古地磁気学的制約 : 東北日本に おける中新世島弧内変形。地質雑，103，523-542.)

関東地方北部の茂木地域において下部中新統火山岩類に対し古地磁気測定を行った。 $17 \mathrm{Ma}$ 前 後に噴出した溶岩流のみならず, 約 $18 \mathrm{Ma}$ の玄武岩シルも南北方向の残留磁化方位を示す。得 られた結果をむとに $18 \mathrm{Ma}$ 以後の茂木地域と北中国地塊との相対回転角を算出すると, 有為な 回転を認め得ることはできない。したがって，茂木地域は約 $18 \mathrm{Ma}$ 以降，大陸に対して有意な 回転運動を経験していないと結論できる，既存の古地磁気デー夕は，北上山地とその周辺地域む 約 $16 \mathrm{Ma}$ 以降回転していないことを意味しており，東北日本の前弧域は少なくとも $16 \mathrm{Ma}$ 以降 は単一のブロックとして回転せずに振舞ってきたと考えられる，一方，関東山地は 15〜 $6 \mathrm{Ma} の$ 間に $90^{\circ}$ にあおよぶ時計廻りの回転を被ったので，東北日本前弧域と関東山地との間にはこの時 期に大規模な差別的回転運動があったことになる，我々はいわゆる関東構造線帯が回転ブロック 境界であったと考える，さらに，今回の結果は東北日本の回転が $15 \mathrm{Ma}$ には終了していたこと を示唆する。 